Article

\title{
Chitosan@Carboxymethylcellulose/CuO- $\mathrm{Co}_{2} \mathrm{O}_{3}$ Nanoadsorbent as a Super Catalyst for the Removal of Water Pollutants
}

\author{
Nujud Maslamani ${ }^{1}$, Esraa M. Bakhsh ${ }^{1, *}$, Sher Bahadar Khan ${ }^{1,2, *}$, Ekram Y. Danish ${ }^{1}{ }^{1}$, Kalsoom Akhtar ${ }^{1}$, \\ Taghreed M. Fagieh ${ }^{1} \mathbb{D}$, Xintai $\mathrm{Su}^{3}$ and Abdullah M. Asiri ${ }^{1,2} \mathbb{E}^{\mathbb{C}}$ \\ 1 Chemistry Department, Faculty of Science, King Abdulaziz University, Jeddah 21589, Saudi Arabia; \\ nujudomar86@gmail.com (N.M.); eydanish@kau.edu.sa (E.Y.D.); kaskhan@kau.edu.sa (K.A.); \\ tfagieh@kau.edu.sa (T.M.F.); aasiri2@kau.edu.sa (A.M.A.) \\ 2 Center of Excellence for Advanced Materials Research, King Abdulaziz University, \\ Jeddah 21589, Saudi Arabia \\ 3 Guangdong Provincial Key Laboratory of Solid Wastes Pollution Control and Recycling, School of \\ Environment and Energy, South China University of Technology, Guangzhou 510006, China; \\ suxintai@scut.edu.cn \\ * Correspondence: ibakhsh@kau.edu.sa (E.M.B.); sbkhan@kau.edu.sa (S.B.K.)
}

check for updates

Citation: Maslamani, N.; Bakhsh, E.M.; Khan, S.B.; Danish, E.Y.; Akhtar, K.; Fagieh, T.M.; Su, X.; Asiri, A.M. Chitosan@Carboxymethylcellulose/ $\mathrm{CuO}-\mathrm{Co}_{2} \mathrm{O}_{3}$ Nanoadsorbent as a Super Catalyst for the Removal of Water Pollutants. Gels 2022, 8, 91. https://doi.org/10.3390/gels8020091

Academic Editor: Maria

Valentina Dinu

Received: 26 November 2021

Accepted: 20 January 2022

Published: 3 February 2022

Publisher's Note: MDPI stays neutral with regard to jurisdictional claims in published maps and institutional affiliations.

Copyright: (C) 2022 by the authors. Licensee MDPI, Basel, Switzerland. This article is an open access article distributed under the terms and conditions of the Creative Commons Attribution (CC BY) license (https:// creativecommons.org/licenses/by/ $4.0 /)$.

\begin{abstract}
In this work, an efficient nanocatalyst was developed based on nanoadsorbent beads. Herein, carboxymethyl cellulose-copper oxide-cobalt oxide nanocomposite beads (CMC/CuO$\mathrm{Co}_{2} \mathrm{O}_{3}$ ) crosslinked by using $\mathrm{AlCl}_{3}$ were successfully prepared. The beads were then coated with chitosan (Cs), $\mathrm{Cs} @ \mathrm{CMC} / \mathrm{CuO}-\mathrm{Co}_{2} \mathrm{O}_{3}$. The prepared beads, $\mathrm{CMC} / \mathrm{CuO}-\mathrm{Co}_{2} \mathrm{O}_{3}$ and $\mathrm{Cs} @ \mathrm{CMC} / \mathrm{CuO}-$ $\mathrm{Co}_{2} \mathrm{O}_{3}$, were utilized as adsorbents for heavy metal ions ( $\mathrm{Ni}, \mathrm{Fe}, \mathrm{Ag}$ and $\mathrm{Zn}$ ). By using $\mathrm{CMC} / \mathrm{CuO}$ $\mathrm{Co}_{2} \mathrm{O}_{3}$ and $\mathrm{Cs} @ \mathrm{CMC} / \mathrm{CuO}-\mathrm{Co}_{2} \mathrm{O}_{3}$, the distribution coefficients $\left(\mathrm{K}_{\mathrm{d}}\right)$ for $\mathrm{Ni}, \mathrm{Fe}, \mathrm{Ag}$ and $\mathrm{Zn}$ were (41.166 and $\left.6173.6 \mathrm{~mL} \mathrm{~g}^{-1}\right),\left(136.3\right.$ and $\left.1500 \mathrm{~mL} \mathrm{~g}^{-1}\right),\left(20,739.1\right.$ and $\left.1941.1 \mathrm{~mL} \mathrm{~g}^{-1}\right)$ and $(86.9$ and $\left.2333.3 \mathrm{~mL} \mathrm{~g}^{-1}\right)$, respectively. Thus, $\mathrm{Ni}$ was highly adsorbed by $\mathrm{Cs} @ \mathrm{CMC} / \mathrm{CuO}-\mathrm{Co}_{2} \mathrm{O}_{3}$ beads. The metal ion adsorbed on the beads were converted into nanoparticles by treating with reducing agent $\left(\mathrm{NaBH}_{4}\right)$ and named Ni/Cs@CMC/CuO- $\mathrm{Co}_{2} \mathrm{O}_{3}$. Further, the prepared nanoparticles-decorated beads (Ni/Cs@CMC/CuO- $\mathrm{Co}_{2} \mathrm{O}_{3}$ ) were utilized as nanocatalysts for the reduction of organic and inorganic pollutants (4-nitophenol, $\mathrm{MO}, \mathrm{EY}$ dyes and potassium ferricyanide $\mathrm{K}_{3}\left[\mathrm{Fe}(\mathrm{CN})_{6}\right]$ ) in the presence of $\mathrm{NaBH}_{4}$. Among all catalysts, $\mathrm{Ni} / \mathrm{Cs} @ \mathrm{CMC} / \mathrm{CuO}-\mathrm{Co}_{2} \mathrm{O}_{3}$ had the highest catalytic activity toward $\mathrm{MO}, \mathrm{EY}$ and $\mathrm{K}_{3}\left[\mathrm{Fe}(\mathrm{CN})_{6}\right]$, removing up to $98 \%$ in $2.0 \mathrm{~min}, 90 \%$ in $6.0 \mathrm{~min}$ and $91 \%$ in $6.0 \mathrm{~min}$, respectively. The reduction rate constants of MO, EY, 4-NP and $\mathrm{K}_{3}\left[\mathrm{Fe}(\mathrm{CN})_{6}\right]$ were $1.06 \times 10^{-1}$, $4.58 \times 10^{-3}, 4.26 \times 10^{-3}$ and $5.1 \times 10^{-3} \mathrm{~s}^{-1}$, respectively. Additionally, the catalytic activity of the $\mathrm{Ni} / \mathrm{Cs} @ \mathrm{CMC} / \mathrm{CuO}-\mathrm{Co}_{2} \mathrm{O}_{3}$ beads was effectively optimized. The stability and recyclability of the beads were tested up to five times for the catalytic reduction of $\mathrm{MO}, \mathrm{EY}$ and $\mathrm{K}_{3}\left[\mathrm{Fe}(\mathrm{CN})_{6}\right]$. It was confirmed that the designed nanocomposite beads are ecofriendly and efficient with high strength and stability as catalysts for the reduction of organic and inorganic pollutants.
\end{abstract}

Keywords: chitosan; $\mathrm{CMC} ; \mathrm{CuO}-\mathrm{Co}_{2} \mathrm{O}_{3}$; nanocomposite beads; inorganic and organic pollutants

\section{Introduction}

Water pollution and its treatment is one of the most serious issues worldwide. Effluent discharge is produced from human activities including industrialization, which introduces a considerable amount of wastewater into nature [1]. Organic contaminates are the most noticeable water pollutants (e.g., organic dyes and nitrophenol compounds), which have deteriorating effects on human health and other living organisms due to their carcinogenic effect on nature [2]. Beside organic contaminations, inorganic pollutants are also considered as the most serious environmental problem including heavy metal ions. According to the literature, the accumulation of toxic metal ions in wastewater can cause genetic alteration, which can affect hormone metabolism and lead to serious diseases such as cancer and fetal 
growth restriction. As reported in the literature, potassium hexacyanoferrate (III) is another example of an inorganic pollutant; it can cause acute toxicity and carcinogenicity even at trace levels [3,4].

Various procedures have been reported as effective methods for pollutants' removal from wastewater such as reverse osmosis, distillation, ion-exchange, coagulation-flocculation, filtration, extraction and adsorption by nanoscale materials [5-7]. Recently, newly designed cost-effective, economic, nontoxic and productive nanoscale materials have been gained attention in various scientific areas such as the water treatment, drug delivery and solar energy conversion fields. Adsorbent-based nanoscale materials are a highly effective way to remove contaminates from wastewater [8-10]. Due to their ease of operation, convenience, low-cost and high efficiency with respect to the removal of metal ions, minerals [11], activated carbon [12], agricultural waste [13], metal oxide nanoparticles, etc., are widely utilized as adsorbents. Among various nanoadsorbents, metal oxide is potentially an excellent nanoadsorbent due to its unique optical properties, large surface area and low toxicity, thus showing great potential in water treatment and high activities [14]. However, combinations of metal oxide nanoparticles come across two main obstacles in their application. Metal oxide nanoparticles tend to react with the surrounding media, and aggregation easily occurs due of van der Waals interactions or agglomerates, leading to a loss in their activity $[15,16]$. Separation of metal oxide nanoparticles from solutions for recycling is another obstacle due to their small size. To solve this problem, metal oxide nanoparticles can be coated with a supported polymer.

Eco-friendly polymeric materials have been rapidly developed for broad range of applications and attracted much attention due to their unique proprieties, including improvement of the efficiency of adsorption, cost effectiveness, biocompatibility and their promising results in the treatment of wastewater [17-19]. Among many other polymers, carboxymethylcellulose (CMC) is a biopolymer of a cellulose derivative with multiple carboxylic and hydroxyl functional groups. CMC has been applied in removal of dyes and metal ions due to its low cost, nontoxicity, biodegradability, biocompatibility and renewability $[4,20]$.There is one limitation of pure CMC, which is its low mechanical strength. However, this drawback could be overcome by an addition of nanofillers or nanocomposites to the CMC polymer. In recent years, researchers have focused on a combination of CMC-nanocomposite beads due to their superior properties. CMC-nanocomposite beads are physically or chemically crosslinked with trivalent metals such as $\mathrm{Fe}^{+3}$ or $\mathrm{Al}^{+3}$, forming coordination bonds between metal ions and $(-\mathrm{COOH})$ in the polymer side chain $[4,21,22]$.

Chitosan with aminopolysaccharide is another biodegradable polymer, which has been vastly studied for various applications due to its great characteristics (e.g., nontoxicity, cost effectiveness, high water permeability, adhesion, cross-linker agent and good coating ability). It has been reported that it has high adsorption aptitude as an adsorbent of heavy metal ions because it has specific physicochemical characteristics (e.g., high hydrophilicity, excellent chelation performance, great number of adsorption sites, high reactivity and selectivity toward metal ions) $[23,24]$. Moreover, the $\mathrm{NH}_{2}$ and $\mathrm{OH}$ groups are the main reactive groups, which are responsible for adsorption of metal ions. Thus, chitosan coating has played a significant role in stabilizing the nanoparticles by coating the surface of the nanosized metal oxide nanoparticles to prevent agglomeration during the adsorption process [25].

Many efforts have been carried out toward the development of $\mathrm{CuO}$ and $\mathrm{Co}_{2} \mathrm{O}_{3}$ as a nanoadsorbent and a nanocatalyst $[16,26]$. At the same time, extensive efforts have been conducted toward the development of different nanocomposites for different applications [27-34]. Based on our survey, $\mathrm{CuO}-\mathrm{Co}_{2} \mathrm{O}_{3}$ with a combination of $\mathrm{CMC}$ and a chitosan coating has not been reported yet. Thus, the combination of novel, facile and green adsorbent nanocomposite beads $\left(\mathrm{CMC} / \mathrm{CuO}-\mathrm{Co}_{2} \mathrm{O}_{3}\right)$ with a chitosan coating to form $\mathrm{Cs} @ \mathrm{CMC} / \mathrm{CuO}-\mathrm{Co}_{2} \mathrm{O}_{3}$ beads was successfully prepared. Both adsorbents were utilized for the removal of metal ions ( $\mathrm{Ni}, \mathrm{Zn}, \mathrm{Ag}$ and $\mathrm{Fe}$ ). In order to recycle the beads, $\mathrm{Ni}(\mathrm{II}) / \mathrm{Cs} @ \mathrm{CMC} / \mathrm{CuO}-\mathrm{Co}_{2} \mathrm{O}_{3}$ and $\mathrm{Ag}(\mathrm{I}) / \mathrm{CMC} / \mathrm{CuO}-\mathrm{Co}_{2} \mathrm{O}_{3}$ were studied. They were 
treated by $\mathrm{NaBH}_{4}$ for the complete conversion to form $\mathrm{Ni}(0) / \mathrm{Cs} @ \mathrm{CMC} / \mathrm{CuO}-\mathrm{Co}_{2} \mathrm{O}_{3}$ and $\mathrm{Ag}(0) / \mathrm{CMC} / \mathrm{CuO}-\mathrm{Co}_{2} \mathrm{O}_{3}$ nanoparticles and then utilized as efficient catalysts for reduction of 4-NP, MO, EY and $\mathrm{K}_{3}\left[\mathrm{Fe}(\mathrm{CN})_{6}\right]$. The prepared nanocomposite beads and the beads were characterized by various analytical techniques, including FT-IR, SEM, EDX and XRD.

\section{Result and Discussion}

\subsection{Characterization}

2.1.1. Field-Emission Scanning Electron Microscope (FE-SEM) Analysis

The surface morphology of the prepared materials, $\mathrm{CuO}-\mathrm{Co}_{2} \mathrm{O}_{3}, \mathrm{CMC}, \mathrm{CMC} / \mathrm{CuO}-$ $\mathrm{Co}_{2} \mathrm{O}_{3}, \mathrm{Cs} @ \mathrm{CMC} / \mathrm{CuO}-\mathrm{Co}_{2} \mathrm{O}_{3}$ and $\mathrm{Ni} / \mathrm{Cs} @ \mathrm{CMC} / \mathrm{CuO}-\mathrm{Co}_{2} \mathrm{O}_{3}$, was examined by utilizing FE-SEM, as seen in Figure 1. The low-magnification and high-magnification images for the prepared nanocomposite beads are represented on the left and right sides in Figure 1. The $\mathrm{CuO}-\mathrm{Co}_{2} \mathrm{O}_{3}$ picture indicates the particles of $\mathrm{CuO}-\mathrm{Co}_{2} \mathrm{O}_{3}$, in Figure 1a,b. The pure CMC beads showed flat surfaces with less porosity [4,35], as seen in Figure 1c,d. On the other hand, $\mathrm{CMC} / \mathrm{CuO}-\mathrm{Co}_{2} \mathrm{O}_{3}$ images illustrated that $\mathrm{CuO}-\mathrm{Co}_{2} \mathrm{O}_{3}$ was planted very well on the CMC surface, as seen in Figure 1e,f. As seen in Figure 1g,h for Cs@CMC/CuO- $\mathrm{Co}_{2} \mathrm{O}_{3}$, chitosan was coated and filled the porous surface of the $\mathrm{CMC} / \mathrm{CuO}-\mathrm{Co}_{2} \mathrm{O}_{3}$. Moreover, Figure 1i,j illustrates that $\mathrm{Ni}$ was rooted and dispersed on $\mathrm{Cs} @ \mathrm{CMC} / \mathrm{CuO}-\mathrm{Co}_{2} \mathrm{O}_{3}$, covering most of the $\mathrm{Cs} @ \mathrm{CMC} / \mathrm{CuO}-\mathrm{Co}_{2} \mathrm{O}_{3}$ surface. The surface area of the metal increased due to the presence of some functional groups such as $\mathrm{COO}-$ on $\mathrm{CMC}$, and $\mathrm{N}_{-} \mathrm{H}_{2}$ and $\mathrm{O}-\mathrm{H}$ on chitosan [36].

\subsubsection{Energy Dispersive X-ray (EDX) Analysis}

For more confirmation of the prepared nanocomposite beads, EDX analysis was applied. As clearly seen from Figure 2, the $\mathrm{Cu}$ and $\mathrm{Co}$ elements were present in the powder $\mathrm{CuO}-\mathrm{Co}_{2} \mathrm{O}_{3}$ and in all prepared beads $\left(\mathrm{CMC} / \mathrm{CuO}-\mathrm{Co}_{2} \mathrm{O}_{3}, \mathrm{Cs} @ \mathrm{CMC} / \mathrm{CuO}-\mathrm{Co}_{2} \mathrm{O}_{3}\right.$ and $\left.\mathrm{Ni} / \mathrm{Cs} @ \mathrm{CMC} / \mathrm{CuO}-\mathrm{Co}_{2} \mathrm{O}_{3}\right)$, confirming the successful synthesis of proposed materials. The carbon and oxygen elements were present in EDX images for $\mathrm{CMC} / \mathrm{CuO}-\mathrm{Co}_{2} \mathrm{O}_{3}$, $\mathrm{Cs} @ \mathrm{CMC} / \mathrm{CuO}-\mathrm{Co}_{2} \mathrm{O}_{3}$ and $\mathrm{Ni} / \mathrm{Cs} @ \mathrm{CMC} / \mathrm{CuO}-\mathrm{Co}_{2} \mathrm{O}_{3}$ due to chitosan and $\mathrm{CMC}$ functional groups [37]. Al element was observed in all beads because $\mathrm{AlCl}_{3}$ was used as a cross-linking agent in the formation of the beads.

\subsubsection{X-ray Diffraction (XRD) Analysis}

The crystal structures and phase purity of nanocomposite beads were examined by XRD analysis. The X-ray diffraction patterns were collected in the $2 \theta$ range of $10-80^{\circ}$, as clearly indicated in Figure 3. As seen in Figure 3a, the XRD pattern of pure CMC showed a broad peak located at $2 \theta=22$ owing to the amorphous CMC crystal [4]. The spectrum of $\mathrm{XRD}$ for the $\mathrm{CuO}-\mathrm{Co}_{2} \mathrm{O}_{3}$ nanocomposite (Figure $3 \mathrm{e}$ ) showed diffraction bands at $2 \theta=35.56$, $38.64,48.84,49.2,60.4,65.0,67.5,70.3$ and 75.2, confirming the monoclinic structure of $\mathrm{CuO}$, which were found at (110), (-111), (111), (-112), (-202), (020), (202) and (-311) [4]. The diffraction peaks at (311), (400), (511), (220) and (440) are responsible for the $\mathrm{Co}_{2} \mathrm{O}_{3}$ phase [38]. Therefore, $\mathrm{CMC} / \mathrm{CuO}-\mathrm{Co}_{2} \mathrm{O}_{3}, \mathrm{Cs} @ \mathrm{CMC} / \mathrm{CuO}-\mathrm{Co}_{2} \mathrm{O}_{3}$ and $\mathrm{Ni} / \mathrm{CMC} / \mathrm{CuO}-$ $\mathrm{Co}_{2} \mathrm{O}_{3}$ have the same diffraction peaks of the $\mathrm{CuO}-\mathrm{Co}_{2} \mathrm{O}_{3}$ nanocomposite, indicating the successful preparation of the beads, as clearly seen in Figure 3b-d. Moreover, the XRD patterns of $\mathrm{Ni} / \mathrm{Cs} @ \mathrm{CMC} / \mathrm{CuO}-\mathrm{Co}_{2} \mathrm{O}_{3}$ beads showed peaks located at (111), (200) and (220), which are attributed to the $\mathrm{Ni}$ phase on the surface of $\mathrm{Ni} / \mathrm{Cs} @ \mathrm{CMC} / \mathrm{CuO}-\mathrm{Co}_{2} \mathrm{O}_{3}$ beads. 

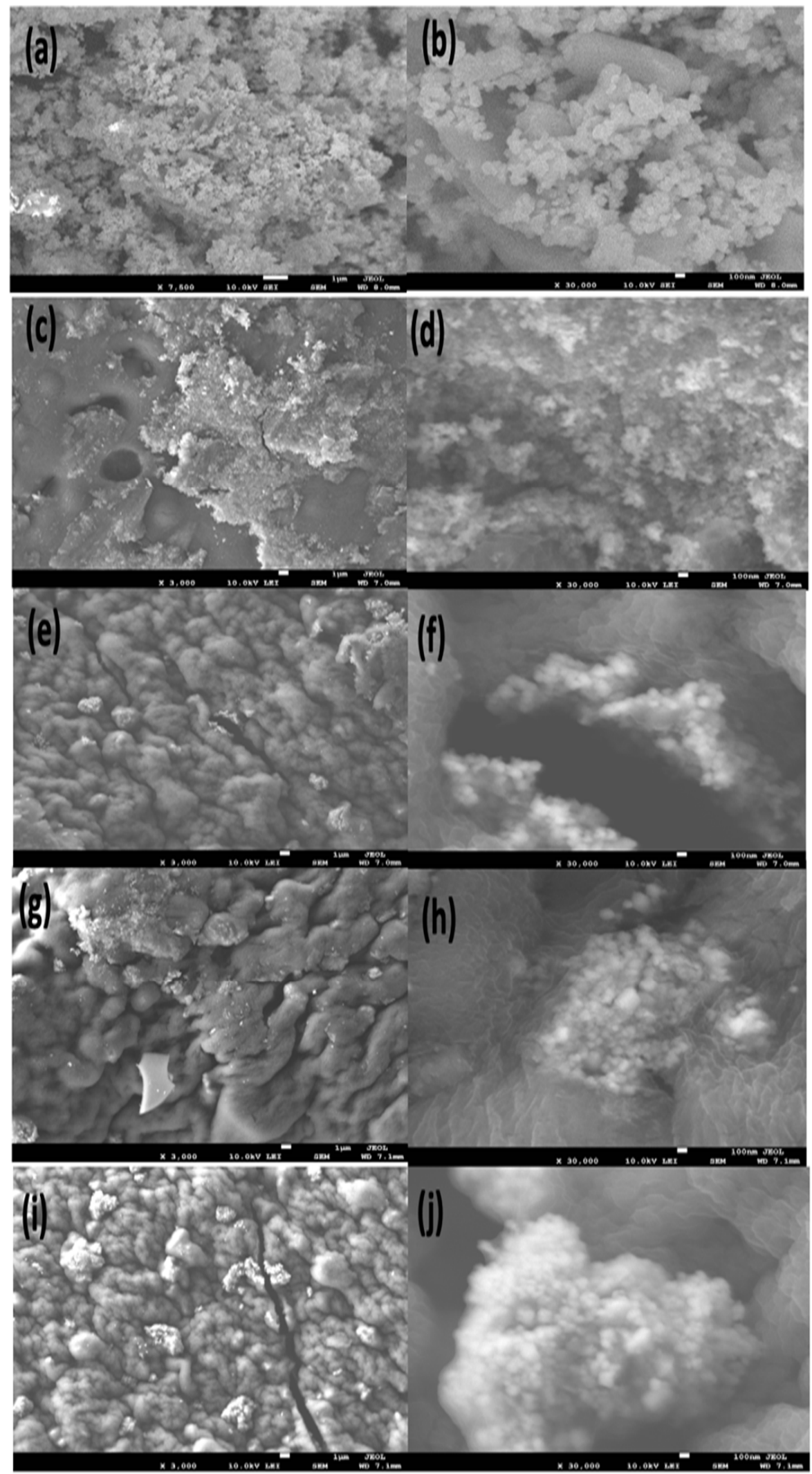

Figure 1. FE-SEM images of $(\mathbf{a}, \mathbf{b}) \mathrm{CuO}-\mathrm{Co}_{2} \mathrm{O}_{3},(\mathbf{c}, \mathbf{d}) \mathrm{CMC},(\mathbf{e}, \mathbf{f}) \mathrm{CMC} / \mathrm{CuO}-\mathrm{Co}_{2} \mathrm{O}_{3},(\mathbf{g}, \mathbf{h}) \mathrm{Cs} @ \mathrm{CMC} /$ $\mathrm{CuO}-\mathrm{Co}_{2} \mathrm{O}_{3}$ and $(\mathbf{i}, \mathbf{j}) \mathrm{Ni} / \mathrm{Cs} @ \mathrm{CMC} / \mathrm{CuO}-\mathrm{Co}_{2} \mathrm{O}_{3}$. 

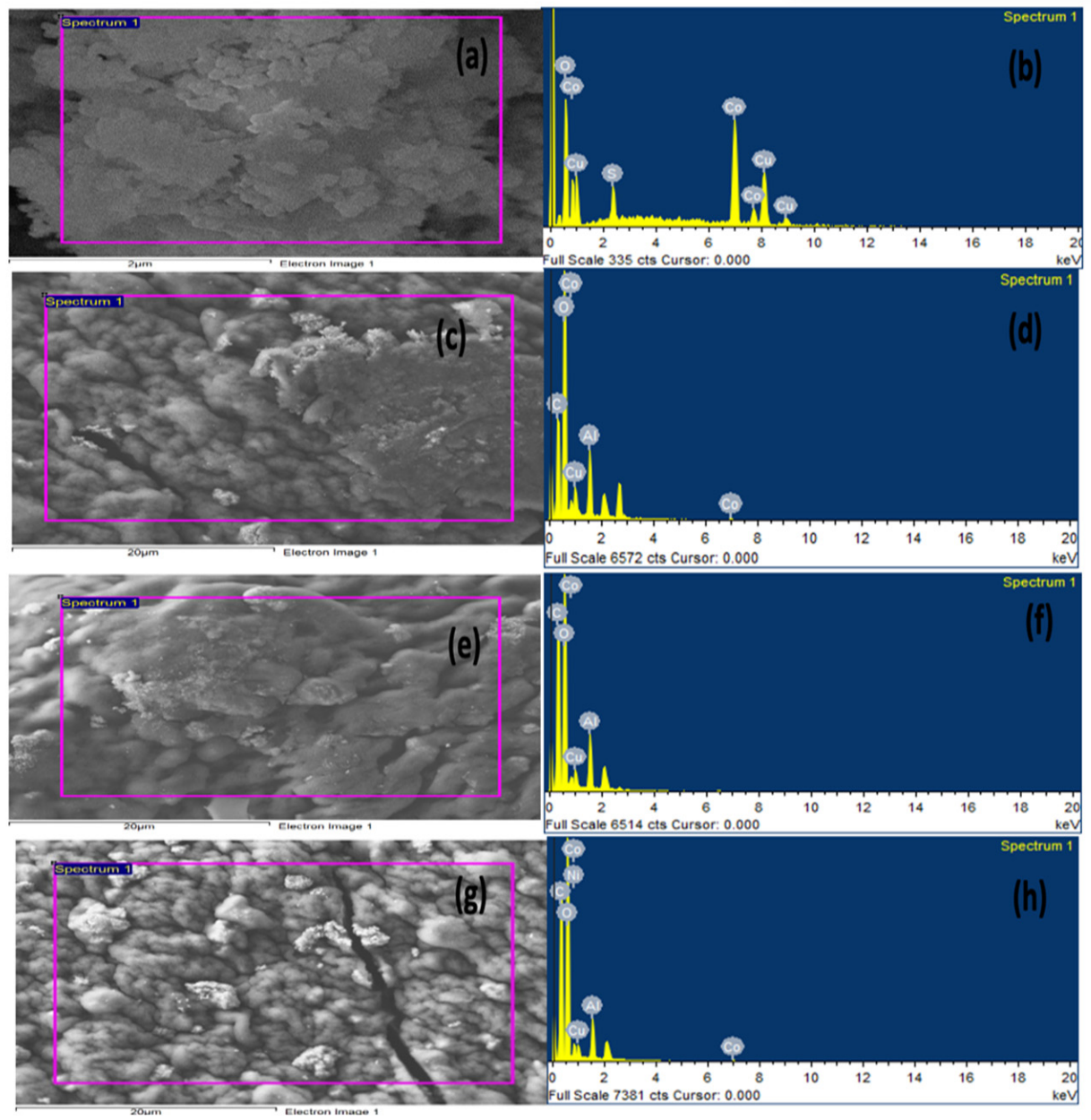

Figure 2. EDX spectra of $(\mathbf{a}, \mathbf{b}) \mathrm{CuO}-\mathrm{Co}_{2} \mathrm{O}_{3},(\mathbf{c}, \mathbf{d}) \mathrm{CMC} / \mathrm{CuO}-\mathrm{Co}_{2} \mathrm{O}_{3},(\mathbf{e}, \mathbf{f}) \mathrm{Cs} @ \mathrm{CMC} / \mathrm{CuO}-\mathrm{Co}_{2} \mathrm{O}_{3}$ and $(\mathbf{g}, \mathbf{h}) \mathrm{Ni} / \mathrm{Cs} @ \mathrm{CMC} / \mathrm{CuO}-\mathrm{Co}_{2} \mathrm{O}_{3}$.

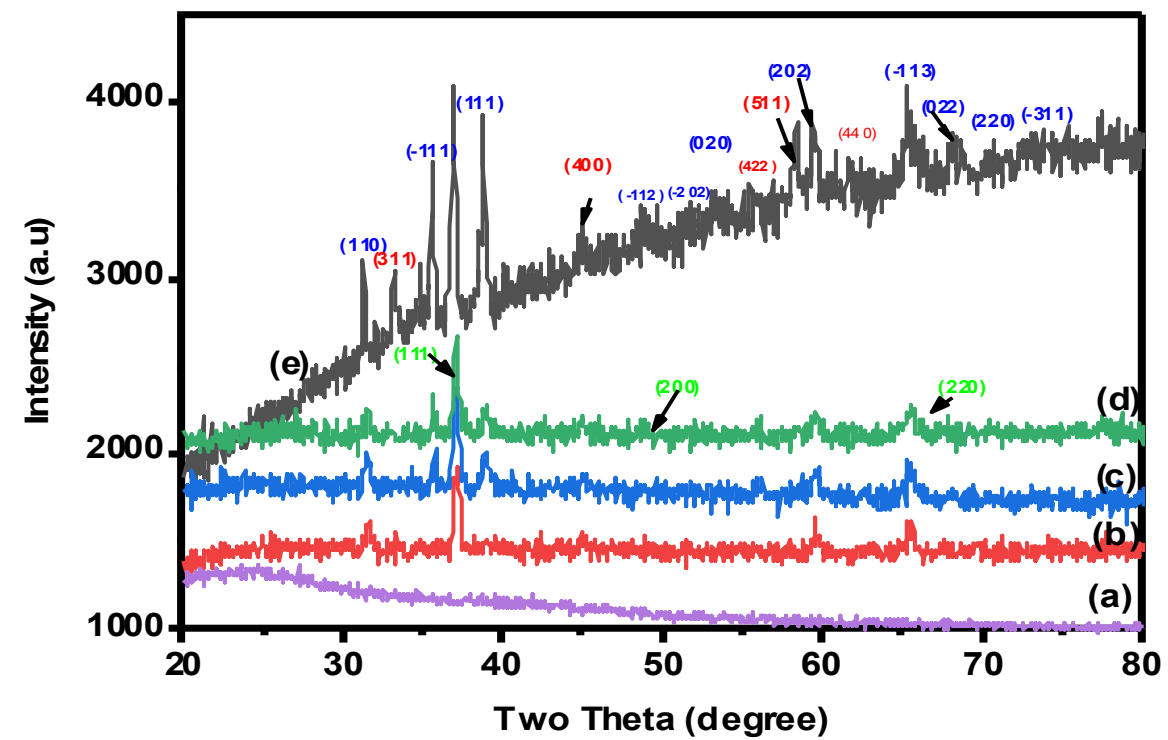

Figure 3. XRD patterns for (a) $\mathrm{CMC}$, (b) $\mathrm{CMC} / \mathrm{CuO}-\mathrm{Co}_{2} \mathrm{O}_{3}$, (c) $\mathrm{Cs} @ \mathrm{CMC} / \mathrm{CuO}-\mathrm{Co}_{2} \mathrm{O}_{3},(\mathbf{d}) \mathrm{Ni} / \mathrm{Cs} @ \mathrm{CMC} /$ $\mathrm{CuO}-\mathrm{Co}_{2} \mathrm{O}_{3}$ and $(\mathbf{e}) \mathrm{CuO}-\mathrm{Co}_{2} \mathrm{O}_{3}$. 


\subsubsection{FT-IR Analysis}

Figure 4 represents the FT-IR spectra of all prepared beads, pure CMC, CMC /CuO$\mathrm{Co}_{2} \mathrm{O}_{3}, \mathrm{Cs} @ \mathrm{CMC} / \mathrm{CuO}-\mathrm{Co}_{2} \mathrm{O}_{3}$ and $\mathrm{Ni} / \mathrm{Cs} @ \mathrm{CMC} / \mathrm{CuO}-\mathrm{Co}_{2} \mathrm{O}_{3}$ along with $\mathrm{CMC} / \mathrm{CuO}-$ $\mathrm{Co}_{2} \mathrm{O}_{3}$ powder. The spectrum of $\mathrm{CuO}-\mathrm{Co}_{2} \mathrm{O}_{3}$ (Figure $4 \mathrm{a}$ ) illustrated a band at $400-600 \mathrm{~cm}^{-1}$, which was assigned to the metal oxides $(\mathrm{M}-\mathrm{O})$; besides a broad band for $\mathrm{O}-\mathrm{H}$ (bending and stretching) [4]. FT-IR spectrum of CMC (Figure 4b) exhibited broad bands at $3300-3500 \mathrm{~cm}^{-1}, 1422$ and 1607, and 1000 and $1200 \mathrm{~cm}^{-1}$, which were assigned to the stretching of -OH groups, symmetrical and asymmetrical stretching vibrations of the $\mathrm{COO}$ groups and $-\mathrm{C}-\mathrm{O}$ stretching on the polysaccharide skeleton, respectively [4,39]. All the bands were present in $\mathrm{CMC} / \mathrm{CuO}-\mathrm{Co}_{2} \mathrm{O}_{3}$ (Figure $4 \mathrm{c}$ ), while for chitosan coating beads Cs@CMC/CuO- $\mathrm{Co}_{2} \mathrm{O}_{3}$ (Figure 4d) new bands at 1155 and $1654 \mathrm{~cm}^{-1}$ appeared, which were attributed to the saccharide and $\left(-\mathrm{NH}_{2}\right)$ amine group in chitosan polymer [40]. All the peaks that appeared in the $\mathrm{Ni} / \mathrm{Cs} @ \mathrm{CMC} / \mathrm{CuO}-\mathrm{Co}_{2} \mathrm{O}_{3}$ beads are clearly seen in Figure 4e.

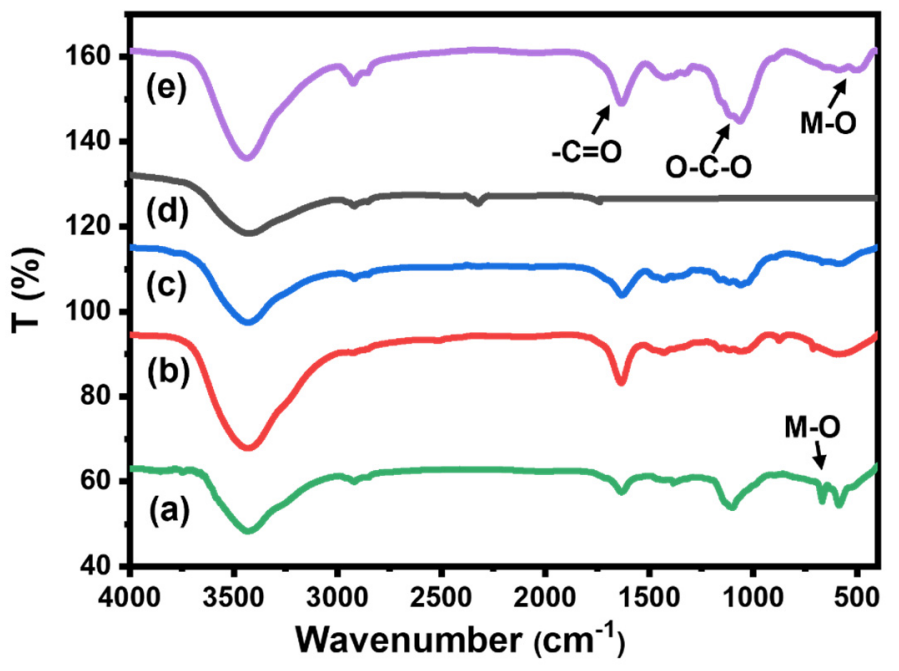

Figure 4. FT-IR spectra for (a) $\mathrm{CuO}-\mathrm{Co}_{2} \mathrm{O}_{3}$, (b) pure CMC, (c) $\mathrm{CMC} / \mathrm{CuO}-\mathrm{Co}_{2} \mathrm{O}_{3}$, (d) $\mathrm{Cs} @ \mathrm{CMC} / \mathrm{CuO}-$ $\mathrm{Co}_{2} \mathrm{O}_{3}$ and (e) Ni/Cs@CMC/CuO- $\mathrm{Co}_{2} \mathrm{O}_{3}$.

\subsection{Metal Uptake Study}

To evaluate the amount of metal adsorbed on the surface of $\mathrm{Cs} @ \mathrm{CMC} / \mathrm{CuO}-\mathrm{Co}_{2} \mathrm{O}_{3}$ and $\mathrm{CMC} / \mathrm{CuO}-\mathrm{Co}_{2} \mathrm{O}_{3}$ beads, distribution coefficient $\left(K_{d}\right)$ and uptake capacity $\left(\mathrm{q}_{\mathrm{e}}\right)$ were calculated using the following Equations (1) and (2) [41]:

$$
\begin{aligned}
K_{\mathrm{d}} & =\frac{(C i-C e)}{C e} * \frac{V(m l)}{m(g)} \\
\mathrm{q}_{\mathrm{e}} & =\frac{(C i-C e) * V(L)}{m(g)}
\end{aligned}
$$

where $C_{i}$ and $C_{e}$ are the concentration of the metal ions before and after adsorption by $\mathrm{Cs} @ \mathrm{CMC} / \mathrm{CuO}-\mathrm{Co}_{2} \mathrm{O}_{3}$ and $\mathrm{CMC} / \mathrm{CuO}-\mathrm{Co}_{2} \mathrm{O}_{3}$ nanocomposite beads, respectively. $V$ refers to the solution volume $(\mathrm{L})$, and $\mathrm{m}$ is the mass of beads $(\mathrm{g})$.

As can be seen from Table 1, Ni has the highest removal percentage with $\mathrm{Cs@CMC/CuO-}$ $\mathrm{Co}_{2} \mathrm{O}_{3}$ compared to other metals, $(66,86.06,70$ and 79\%) for $\mathrm{Ag}(\mathrm{I}), \mathrm{Ni}(\mathrm{II}), \mathrm{Zn}(\mathrm{II})$ and $\mathrm{Fe}(\mathrm{II})$, respectively. When compared the adsorbed metals, $\mathrm{Ag}(\mathrm{I})$ has the highest adsorption (\%) with $\mathrm{CMC} / \mathrm{CuO}-\mathrm{Co}_{2} \mathrm{O}_{3}$ up to $95 \%$. This result indicates that $\mathrm{Ag}(\mathrm{I})$ was more adsorbed by $\mathrm{CMC} / \mathrm{CuO}-\mathrm{Co}_{2} \mathrm{O}_{3}$ beads, and $\mathrm{Ni}(\mathrm{II})$ was more adsorbed by $\mathrm{Cs} @ \mathrm{CMC} / \mathrm{CuO}-\mathrm{Co}_{2} \mathrm{O}_{3}$ beads. However, the $\mathrm{Cs} @ \mathrm{CMC} / \mathrm{CuO}-\mathrm{Co}_{2} \mathrm{O}_{3}$ adsorbent was more effective than the $\mathrm{CMC} / \mathrm{CuO}$ $\mathrm{Co}_{2} \mathrm{O}_{3}$ beads toward all metals, as shown in Figure 5 . The reason for this is that chitosan has strong chelating proprieties toward metal ions due to the high content of amino and hydroxyl groups present in the composition of chitosan, which act as active sites $[15,42,43]$. 
Table 1. Uptake capacity of $\mathrm{Ni}, \mathrm{Fe}, \mathrm{Zn}$ and $\mathrm{Ag}$ ions on $\mathrm{CMC} / \mathrm{CuO}-\mathrm{Co}_{2} \mathrm{O}_{3}$ and $\mathrm{Cs} @ \mathrm{CMC} / \mathrm{CuO}-\mathrm{Co}_{2} \mathrm{O}_{3}$ beads

\begin{tabular}{|c|c|c|c|c|c|c|c|c|c|c|}
\hline \multirow[b]{2}{*}{ Metal Ions } & \multirow{2}{*}{$\begin{array}{l}\text { Wavelength } \\
\text { Detection (nm) }\end{array}$} & \multirow{2}{*}{$\begin{array}{l}\text { Initial Conc. } \\
\left(\mathrm{mgL}^{-1}\right)\end{array}$} & \multicolumn{4}{|c|}{$\mathrm{CMC} / \mathrm{CuO}-\mathrm{Co}_{2} \mathrm{O}_{3}$} & \multicolumn{4}{|c|}{$\mathrm{Cs} @ \mathrm{CMC} / \mathrm{CuO}-\mathrm{Co}_{2} \mathrm{O}_{3}$} \\
\hline & & & $\begin{array}{l}\text { Final Conc. } \\
\left(\mathrm{mgL}^{-1}\right)\end{array}$ & $\begin{array}{c}\mathrm{q}_{\mathrm{e}} \\
\left(\mathrm{mgg}^{-1}\right)\end{array}$ & $\underset{\left(\mathrm{mLg}^{-1}\right)}{\mathrm{K}_{\mathrm{d}}}$ & $\begin{array}{c}\mathrm{R} \\
(\%)\end{array}$ & $\begin{array}{l}\text { Final Conc. } \\
\left(\mathrm{mgL}^{-1}\right)\end{array}$ & $\begin{array}{c}\mathrm{q}_{\mathrm{e}} \\
\left(\mathrm{mgg}^{-1}\right)\end{array}$ & $\underset{\left(m L g^{-1}\right)}{\mathrm{K}_{\mathrm{d}}}$ & $\begin{array}{c}R \\
(\%)\end{array}$ \\
\hline $\mathrm{Ni}(\mathrm{II})$ & 221.648 & 5 & 4.8 & 0.2 & 41.666 & 4 & 0.697 & 4.3 & 6173.6 & 86.06 \\
\hline $\mathrm{Zn}(\mathrm{II})$ & 213.9 & 5 & 4.6 & 0.4 & 86.956 & 8 & 1.5 & 3.5 & 2333.3 & 70 \\
\hline $\mathrm{Fe}(\mathrm{II})$ & 248 & 5 & 4.4 & 0.6 & 136.363 & 12 & 2 & 3 & 1500 & 60 \\
\hline $\operatorname{Ag}(\mathrm{I})$ & 243.778 & 5 & 0.23 & 5 & $20,739.1$ & 95.4 & 1.7 & 3.3 & 1941.1 & 66 \\
\hline
\end{tabular}

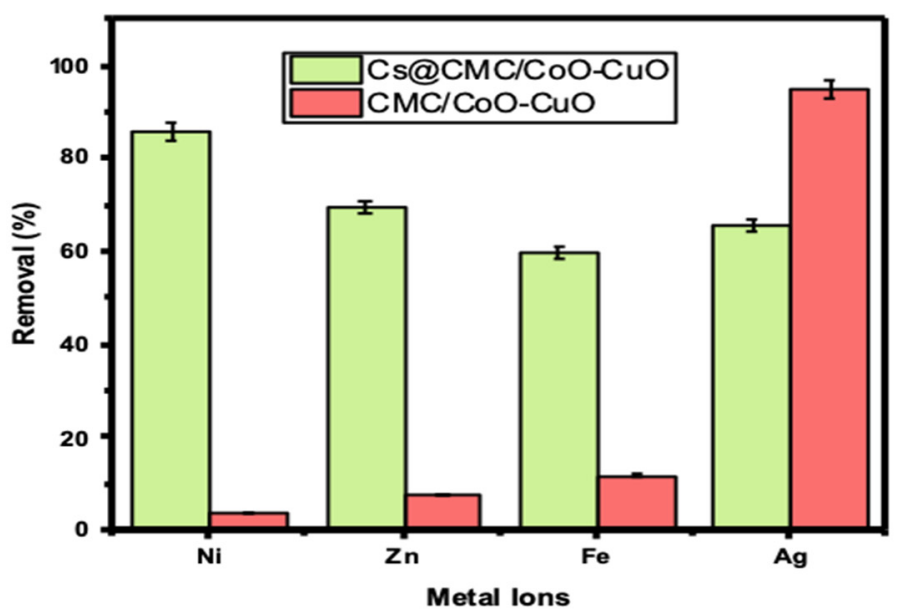

Figure 5. Removal percentage of metal ions using $5 \mathrm{mg}$ of $\mathrm{CMC} / \mathrm{CuO}-\mathrm{Co}_{2} \mathrm{O}_{3}$ and $\mathrm{Cs} @ \mathrm{CMC} / \mathrm{CuO}-$ $\mathrm{Co}_{2} \mathrm{O}_{3}$ vigorously shaken for $60 \mathrm{~min}$ at $\mathrm{RT}\left(25 \pm 1^{\circ} \mathrm{C}\right)$.

\subsection{Optimization of Ni(II) Adsorption}

\subsubsection{Effect of Initial Concentration of $\mathrm{Ni}(\mathrm{II})$ Solution}

As shown in Figure 6a, the influence of different concentrations of Ni(II) ions was tested to evaluate the adsorption isotherms. According to literature, the adsorption efficiency decreases with the increase in $\mathrm{Ni}(\mathrm{II})$ concentration as proved in most studies on heavy metals removal. The possible explanation is that the adsorbent surface sites are enough to accommodate the metal ions in solution and the sorption rate gets faster. However, when the metal concentrations are increased, the adsorbent surface sites will not be enough to capture all the metal ions present in the solution [44].

\subsubsection{Effect of $\mathrm{pH}$ of $\mathrm{Ni}(\mathrm{II})$ Solution}

The effect of $\mathrm{pH}$ was the most significant controlling parameter in the adsorption study. Adsorption of heavy metals depends on the $\mathrm{pH}$ and the type of ions solution. For heavy metal adsorption, a pH range of 5.0-8.0 is usually sufficient. Due to the decrease in $\mathrm{H}^{+}$concentration, heavy metal ions exist as free ions with an initial $\mathrm{pH}$ range of 4.0-5.0 and can be adsorbed onto chitosan at higher $\mathrm{pH}$ values. Because $\mathrm{H}^{+}$concentration is high at lower $\mathrm{pH}$ values, protonation of amino groups can cause electrostatic repulsion between protonated group and heavy metal ions. The net negative charge on the surface of chitosan increases when the $\mathrm{pH}$ value rises, and the ionic point of ligands such as $-\mathrm{COOH},-\mathrm{OH}$ and $-\mathrm{NH}_{2}$ groups becomes free, enhancing binding with the heavy metal ions. It has been reported that at $\mathrm{pH}$ values less than 6.5 , chitosan has strong cationic charges and strong anionic charges at $\mathrm{pH}$ higher than 6.5. In our adsorbent beads, the carboxylic $(-\mathrm{COOH})$ and amino $\left(-\mathrm{NH}_{2}\right)$ groups existing in the beads are responsible for the binding of $\mathrm{Ni}$ (II). Therefore, various values of $\mathrm{pH}$ for $\mathrm{Ni}$ ions solution were examined using the adsorbent $\mathrm{Cs} @ \mathrm{CMC} / \mathrm{CuO}-\mathrm{Co}_{2} \mathrm{O}_{3}$ nanocomposite beads, as illustrated in Figure 6b. It was clearly found that the adsorption of $\mathrm{Ni}$ ions increased with an increase in $\mathrm{pH}$ from 3 to 7 (neutral); and the removal efficiency was $1 \%, 29 \%$ and $83 \%$ for $\mathrm{pH}$ values 3,5 and 7 , respectively. However, the adsorption then reduced greatly with an increase in the $\mathrm{pH}$ from 7 to 9 . The 
reduction in adsorption at high $\mathrm{pH}$ may be either due to aggregation of chitosan polymer because of the hard protonation of its amino groups, or may be due to the precipitation of metal ions or $\mathrm{Ni}$ ions in the alkaline medium as $\mathrm{Ni}(\mathrm{OH})_{2}$. [45]. Therefore, the neutral $\mathrm{pH}$ was selected as an optimal condition for further experiments. The same effect was reported in the literature $[26,46,47]$.

(a)

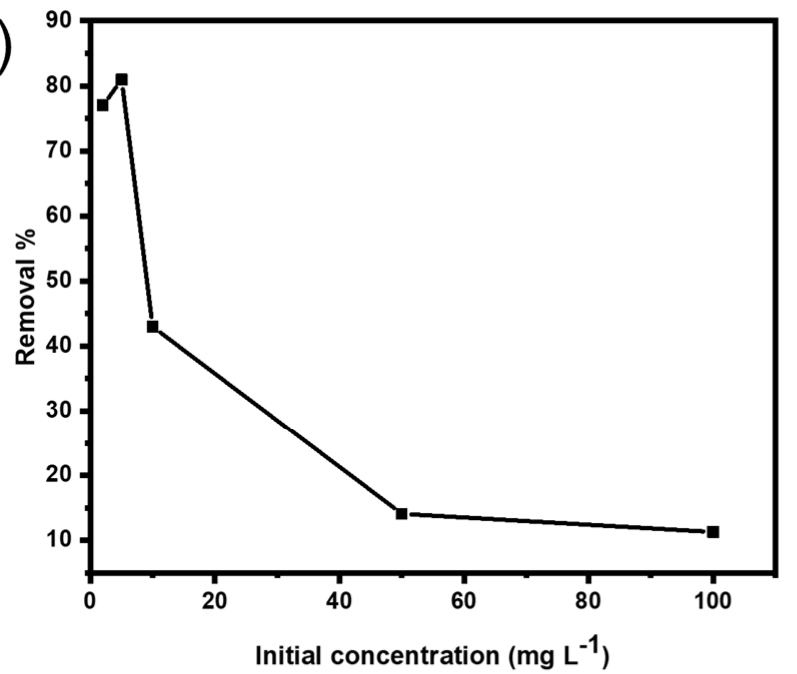

(c)

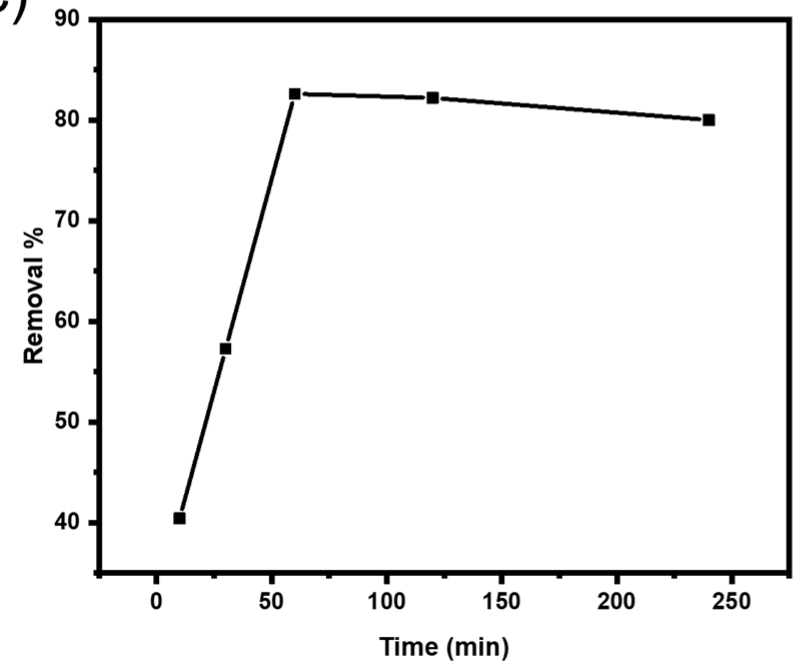

(b)

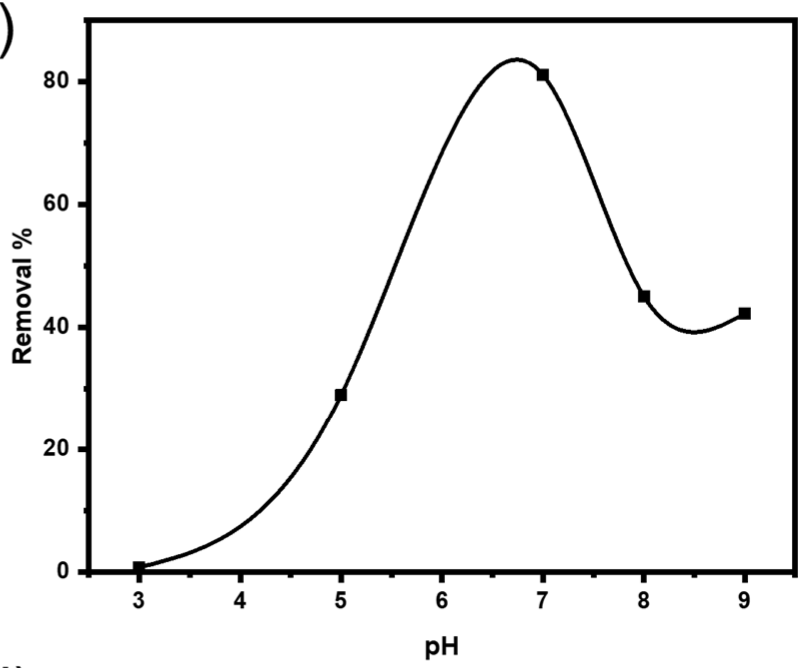

(d)

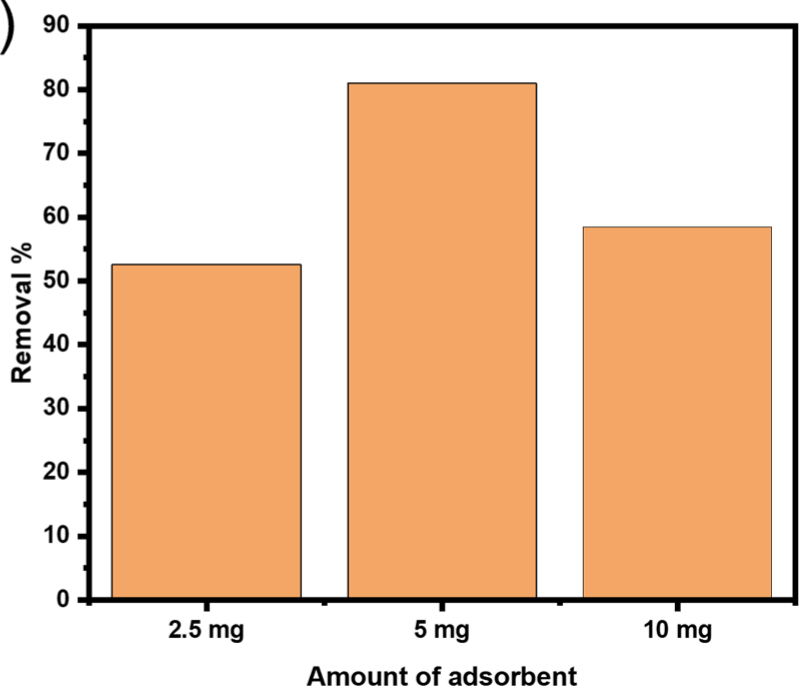

Figure 6. (a) Effect of $\mathrm{Ni}(\mathrm{II})$ initial concentration using $5 \mathrm{mg} \mathrm{Cs} @ \mathrm{CMC} / \mathrm{CuO}-\mathrm{Co}_{2} \mathrm{O}_{3}$ at $\mathrm{pH}=7$. (b) Effect of pH using $5 \mathrm{mg} \mathrm{L}{ }^{-1} \mathrm{Ni}(\mathrm{II})$ and $5 \mathrm{mg} \mathrm{Cs} @ \mathrm{CMC} / \mathrm{CuO}-\mathrm{Co}_{2} \mathrm{O}_{3}$. (c) Effect of contact time using 5 mg L ${ }^{-1} \mathrm{Ni}(\mathrm{II})$ and $5 \mathrm{mg} \mathrm{Cs} @ \mathrm{CMC} / \mathrm{CuO}-\mathrm{Co}_{2} \mathrm{O}_{3}$ at $\mathrm{pH}=7$. (d) Effect of $\mathrm{Cs} @ \mathrm{CMC} / \mathrm{CuO}-\mathrm{Co}_{2} \mathrm{O}_{3}$ dose at $\mathrm{pH}=7$.

\subsubsection{Effect of Ni(II) Adsorption Contact Time}

The effect of contact time is a significant factor in adsorption study. In fact, the adsorption property is very dependent on the time required for equilibrium between the adsorbent and adsorbate. The adsorption of $\mathrm{Ni}$ ions was carried out by applying different contact times (10, 30, 60, 120, $240 \mathrm{~min})$. As clearly seen from Figure 6c, 48.6\% of Ni(II) was removed in $10 \mathrm{~min}$ and reached $88.7 \%$ in $60 \mathrm{~min}$ before it gradually decreased to $62 \%$ at $240 \mathrm{~min}$. The explanation for this phenomenon is that in the first $60 \mathrm{~min}$, the surface of the $\mathrm{Cs} @ \mathrm{CMC} / \mathrm{CuO}-\mathrm{Co}_{2} \mathrm{O}_{3}$ was filled with the $\mathrm{Ni}(\mathrm{II})$, and the whole surface was occupied, but the adsorption process was gradually reduced after $60 \mathrm{~min}$ due to the saturation of active sites on the beads' surface. This result is in accordance with previous published findings [48]. 


\subsubsection{Effect of Adsorbent Dose}

The adsorbent dose is also an important factor in adsorption. To evaluate the effect of the adsorbent amount on Ni removal, three different doses of CS@CMC $/ \mathrm{CuO}-\mathrm{Co}_{2} \mathrm{O}_{3}$ beads $(2.5,5$ and $10 \mathrm{mg})$ were used for a fixed initial $\mathrm{Ni}(\mathrm{II})$ concentration $\left(5 \mathrm{mg} \mathrm{L}^{-1}\right)$ at $25{ }^{\circ} \mathrm{C}$ with a contact time of $60 \mathrm{~min}$. As clearly seen in Figure $6 \mathrm{~d}$, the removal percentage of $\mathrm{Ni}$ (II) was increased from $53 \%$ to $83 \%$ when the number of beads increased from 2.5 to $5 \mathrm{mg}$, respectively. However, the removal percentage was then decreased with an increase in bead dosage from 5 to $10 \mathrm{mg}$. The best explanation for this phenomenon is that the $\mathrm{CS} @ \mathrm{CMC} / \mathrm{CuO}-\mathrm{Co}_{2} \mathrm{O}_{3}$ beads have more active sites, which remined unsaturated during the adsorption procedure. Therefore, $5 \mathrm{mg}$ was fixed for further study as the optimum adsorbent dose.

Moreover, the isotherm and kinetic adsorption were studied as follows: The two isotherm models, Langmuir and Freundlich, are given in Table 2 (Equations (4) and (5)) to model the adsorption process of our system. According to the data obtained, the correlation coefficient $\left(\mathrm{R}^{2}\right)$ values for isotherm models, Langmuir was discovered to be a suitable model to represent the sorption system, which assumed a monolayer of analyte establisher on a homogeneous surface of the adsorbent. Linearity of plotting $C_{e} / q_{e} v s . C_{e}$ was achieved with $\mathrm{R}^{2}$ of 0.9433 . The Langmuir constant $\left(q_{m}\right)$ was calculated to be $12.00 \mathrm{mg} \mathrm{g}^{-1}$, which is close to the experimental value of the adsorption capacity $\left(11.00 \mathrm{mg} \mathrm{g}^{-1}\right)$. The Langmuir constant (b) is equal to $0.08 \mathrm{~L} \mathrm{mg}^{-1}$, which explains the strong affinity of the $\mathrm{Ni}$ (II) ions to the adsorbent beads. The essential factor $\mathrm{R}_{\mathrm{L}}$ was calculated using Equation (3) [44].

$$
\mathrm{R}_{\mathrm{L}}=\frac{1}{1+\mathrm{bC}_{\mathrm{o}}}
$$

where $C_{o}$ is the initial concentration of $\mathrm{Ni}(\mathrm{II})\left(\mathrm{mgL}^{-1}\right)$, and $\mathrm{b}$ is the Langmuir constant. The calculated $R_{L}$ was found to be 0.50 , which is in the range of $0<R_{L}>1$, referring to favorable adsorption. Thus, this confirmed that the adsorption of $\mathrm{Ni}(\mathrm{II})$ ions by $\mathrm{Cs} @ \mathrm{CMC} / \mathrm{CuO}$ $\mathrm{Co}_{2} \mathrm{O}_{3}$ is favorable, as shown in Table 3 .

Table 2. Mathematical equations and isotherm models [49-51] used in this study.

\begin{tabular}{cccc}
\hline & Models & Linear Equations & Plot \\
\hline \multirow{2}{*}{ Isotherm } & Langmuir & $\frac{C_{e}}{\mathrm{q}_{t}}=\frac{1}{q_{m K_{L}}}+\frac{\mathrm{C}_{e}}{q_{m}}(4)$ & $\frac{C_{e}}{\mathrm{q}_{t}}$ vs. $C_{e}$ \\
& Freundlich & $\log q_{e}=\log K_{f}+\frac{1}{n} \log C_{e}(5)$ & $\log q_{e}$ vs. $\log C_{e}$ \\
\multirow{2}{*}{ Kinetic } & Pseduo-first-order & $\log \left(\mathrm{q}_{e}-\mathrm{q}_{t}\right)=\log \mathrm{q}_{e}-\left(k_{1} / 2.303\right) \mathrm{t}(6)$ & $\log \left(\mathrm{q}_{e}-\mathrm{q}_{t}\right)$ vs. $t$ \\
& Pseduo-second-order & $\frac{t}{\mathrm{q}_{t}}=\frac{1}{v_{o}}+\frac{1}{\mathrm{q}_{e}} \mathrm{t}(7)$ & $\frac{t}{\mathrm{q}_{t}}$ vs.t \\
\hline
\end{tabular}

Table 3. Data of isotherm models for $\mathrm{Ni}(\mathrm{II})$ adsorption using $\mathrm{Cs} @ \mathrm{CMC} / \mathrm{CuO}-\mathrm{Co}_{2} \mathrm{O}_{3}$.

\begin{tabular}{cccccccc}
\hline & \multicolumn{4}{c}{ Langmuir Model } & \multicolumn{3}{c}{ Freundlich Model } \\
\hline Metal Ion & $q_{\text {max }}$ & $\mathrm{R}^{2}$ & $R_{L}$ & $\mathrm{~b}\left(\mathrm{Lmg}^{-1}\right)$ & $\mathrm{R}^{2}$ & $k_{f}$ & $\mathrm{n}$ \\
$\mathrm{Ni}(\mathrm{II})$ & 12.00 & 0.943 & 0.50 & 0.08 & 0.553 & 9.10 & 5.06 \\
\hline
\end{tabular}

The pseudo-first-order model and second-order model were applied to the adsorption system for an explanation of kinetics, as shown in Table 2 (Equations (6) and (7)). Both slope and intercept were calculated using the plot $\log \left(q_{e}-q_{t}\right)$ vs. $t$, and $t / q t$ vs. $t$ for the pseudo-first order and the pseudo-second order, respectively. Based on the calculated values, the pseudo-first-order more suitably explained the adsorption. The pseudo-secondorder model was close to the adsorption capacities obtained from experiments; Langmuir isotherm and pseudo-second-order kinetic models were compatible, as illustrated in Table 4. The obtained data were compared with other studies for removal of $\mathrm{Ni}(\mathrm{II})$, as represented in Table 5 . 
Table 4. Kinetic models data for $\mathrm{Ni}(\mathrm{II})$ adsorption by using $5 \mathrm{mg}$ of $\mathrm{Cs} @ \mathrm{CMC} / \mathrm{CuO}-\mathrm{Co}_{2} \mathrm{O}_{3}$.

\begin{tabular}{|c|c|c|c|c|c|c|c|}
\hline \multirow[b]{2}{*}{ Metal Ion } & \multirow{2}{*}{$\begin{array}{l}q_{e}\left(\mathrm{mg} \mathrm{g}^{-1}\right) \\
\text { Experiment }\end{array}$} & \multicolumn{3}{|c|}{ Pseudo-First-Order } & \multicolumn{3}{|c|}{ Pseudo-Second-Order } \\
\hline & & $\mathbf{R}^{2}$ & $\begin{array}{c}\mathrm{K}_{1} \\
\left(\min ^{-1}\right)\end{array}$ & $\begin{array}{c}q_{e} \\
\mathrm{mg} \mathrm{g}^{-1}\end{array}$ & $\mathbf{R}^{2}$ & $\begin{array}{c}\mathrm{K}_{2} \\
\left(\mathrm{~g} \mathrm{mg}^{-1} \min ^{-1}\right)\end{array}$ & $\begin{array}{c}q_{e} \\
\mathrm{mg} \mathrm{g}^{-1}\end{array}$ \\
\hline $\mathrm{Ni}(\mathrm{II})$ & 11.00 & 0.703 & 0.0011 & 2.72 & 0.986 & -0.222 & 4.05 \\
\hline
\end{tabular}

Table 5. Comparison of this study with other reported studies in literature.

\begin{tabular}{|c|c|c|c|c|}
\hline Adsorbent & Metal Ion & Condition & $\mathrm{q}_{\max }\left(\mathrm{mg} \mathrm{g}^{-1}\right)$ & Ref. \\
\hline CS/TEOS/APTES & $\mathrm{Ni}(\mathrm{II})$ & $\mathrm{pH} 5.2,30^{\circ} \mathrm{C}, 30 \mathrm{~min}$ & 696.2 & [48] \\
\hline Chitosan-g-maleic acid & $\mathrm{Ni}(\mathrm{II})$ & $\mathrm{pH} 8$, room temperature, $60 \mathrm{~min}$ & 73.5 & [26] \\
\hline Flower globular FGMH & $\mathrm{Ni}(\mathrm{II})$ & $\mathrm{pH} 6-7,20^{\circ} \mathrm{C}, 50 \mathrm{~min}$ & 248 & [52] \\
\hline Chitosan-MOF & $\mathrm{Ni}(\mathrm{II})$ & $\mathrm{pH} 5,20^{\circ} \mathrm{C}, 480 \mathrm{~min}$ & 56 & [53] \\
\hline $\mathrm{Cs} @ \mathrm{CMC} / \mathrm{CuO}-\mathrm{Co}_{2} \mathrm{O}_{3}$ & $\mathrm{Ni}(\mathrm{II})$ & $\mathrm{pH} 7$, room temperature, $60 \mathrm{~min}$ & 11 & This study \\
\hline
\end{tabular}

\subsection{Adsorption Mechanism}

The possible adsorption mechanism is illustrated in Figure 7. The adsorption of heavy metals with $\mathrm{Cs} @ \mathrm{CMC} / \mathrm{CuO}-\mathrm{Co}_{2} \mathrm{O}_{3}$ might be due to strong attraction of metal ions to nanocomposite beads, which contain active sites $\left(\mathrm{COO}-, \mathrm{OH}, \mathrm{Cu}-\mathrm{O}, \mathrm{Co}-\mathrm{O},-\mathrm{O}-\right.$ and $\left.-\mathrm{NH}_{2}\right)$. These groups can easily attract and combined with metal ions. However, the amino group in chitosan has a significant role in the adsorption because the chitosan completely coats the surface of $\mathrm{CMC} / \mathrm{CuO}-\mathrm{Co}_{2} \mathrm{O}_{3}$. The chemical nature of chitosan, hydrophilicity due to the large number of $(-\mathrm{OH})$ and the presence of $\left(-\mathrm{NH}_{2}\right)$ can determine the adsorption of chitosan toward the heavy metal. According to the literature, the adsorption of heavy metal ions by chitosan functional groups can occur based on different mechanisms (e.g., electrostatic attraction and chelation). Chitosan $\left(\mathrm{NH}_{2}\right)$ groups are responsible for the adsorption of metal cations by a chelation mechanism. In fact, the adsorption can be affected by the $\mathrm{pH}$ of the metal ion solution where the $\mathrm{NH}_{2}$ group (free-electron doublet on nitrogen) can attract cations at neutral $\mathrm{pH}[24,54,55]$.

\subsection{Catalytic Reduction Study}

The catalytic ability of all prepared catalysts, including $\mathrm{CuO}-\mathrm{Co}_{2} \mathrm{O}_{3}, \mathrm{CMC} / \mathrm{CuO}-$ $\mathrm{Co}_{2} \mathrm{O}_{3}, \mathrm{Cs} @ \mathrm{CMC} / \mathrm{CuO}-\mathrm{Co}_{2} \mathrm{O}_{3}$ and $\mathrm{Ni} / \mathrm{Cs} @ \mathrm{CMC} / \mathrm{CuO}-\mathrm{Co}_{2} \mathrm{O}_{3}$, was examined for the reduction of two anionic dyes (MO and $\mathrm{EY}$ ). $\mathrm{MO}$ dye was chosen as a model dye for this study. MO solution $(0.01 \mathrm{mM})$ was placed into a UV-cuvette and mixed with a reducing agent, $\mathrm{NaBH}_{4}$. Further, each catalyst was added to the mixture of $\mathrm{MO}$ and $\mathrm{NaBH}_{4}$ as mentioned previously. Afterward, the reduction reaction of $\mathrm{MO}$ was examined by the $\mathrm{UV}-\mathrm{Vis}$ spectrophotometer every $\mathrm{min}$ as the reaction proceeded. Initially, pure MO solution (0.01 mM) was recorded by UV-Vis, and two absorbance bands appeared at $\lambda_{\max }=460 \mathrm{~nm}$ and $270 \mathrm{~nm}$, as shown in Figure 8. There was no change observed when the reducing agent $\left(\mathrm{NaBH}_{4}\right)$ was added because $\mathrm{NaBH}_{4}$ cannot reduce the dye even with an excess amount, as reported in the literature [56]. However, after the addition of both reducing agent and catalysts, the color of $\mathrm{MO}$ dye disappeared gradually from orange to colorless. The reason for this that $\mathrm{MO}$ was converted to hydrazine derivatives by breaking the azo bond (-N=N-) and transforming it to $-\mathrm{NH}_{2}$ (amino). During the reduction, the peak at $1_{\max }=460 \mathrm{~nm}$ was decreased gradually $[57,58]$. The reduction percentage of $\mathrm{MO}$ was $92 \%$ in 4 min with $\mathrm{Ni} / \mathrm{Cs} @ \mathrm{CMC} / \mathrm{CuO}-\mathrm{Co}_{2} \mathrm{O}_{3}$ while it reached to $85 \%, 90 \%$ and $33.5 \%$ with $\mathrm{CuO}-\mathrm{Co}_{2} \mathrm{O}_{3}$, $\mathrm{CMC} / \mathrm{CuO}-\mathrm{Co}_{2} \mathrm{O}_{3}$ and $\mathrm{Cs} @ \mathrm{CMC} / \mathrm{CuO}-\mathrm{Co}_{2} \mathrm{O}_{3}$ in 5, 20 and $14 \mathrm{~min}$, respectively. Moreover, the reduction of $\mathrm{MO}$ was studied by using the $\mathrm{Ag} / \mathrm{CMC} / \mathrm{CuO}-\mathrm{Co}_{2} \mathrm{O}_{3}$ under the same conditions. It was found that $\mathrm{Ag} / \mathrm{Cs} @ \mathrm{CMC} / \mathrm{CuO}-\mathrm{Co}_{2} \mathrm{O}_{3}$ can reduce $88 \%$ of $\mathrm{MO}$ in $6 \mathrm{~min}$. 


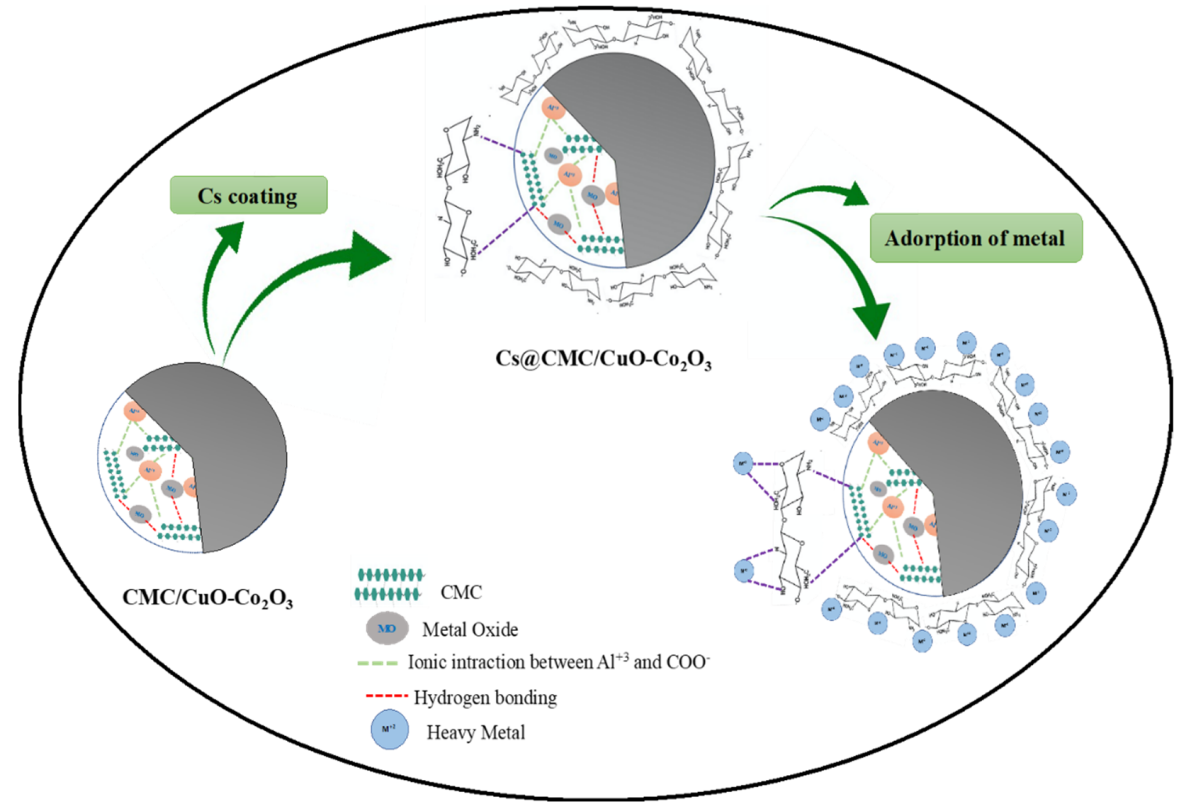

Figure 7. Adsorption mechanism of $\mathrm{Cs} @ \mathrm{CMC} / \mathrm{CuO}-\mathrm{Co}_{2} \mathrm{O}_{3}$ nanocomposite beads with metal ions.

(a)
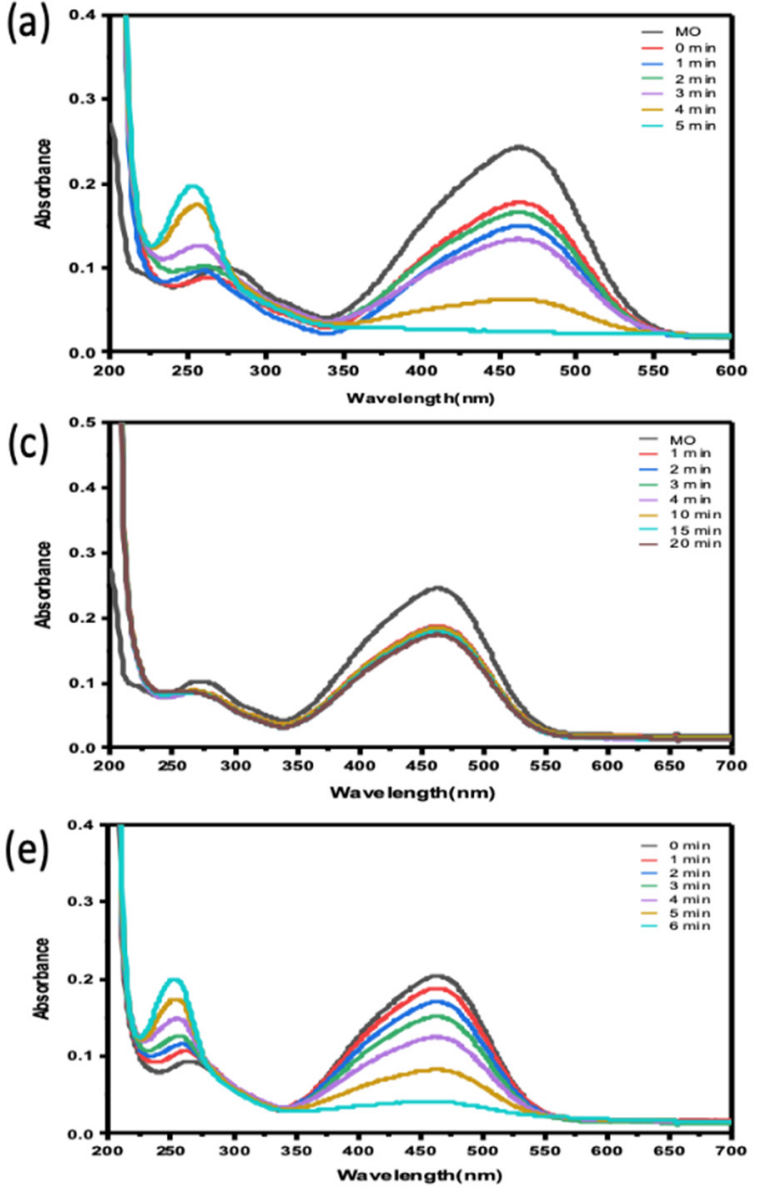
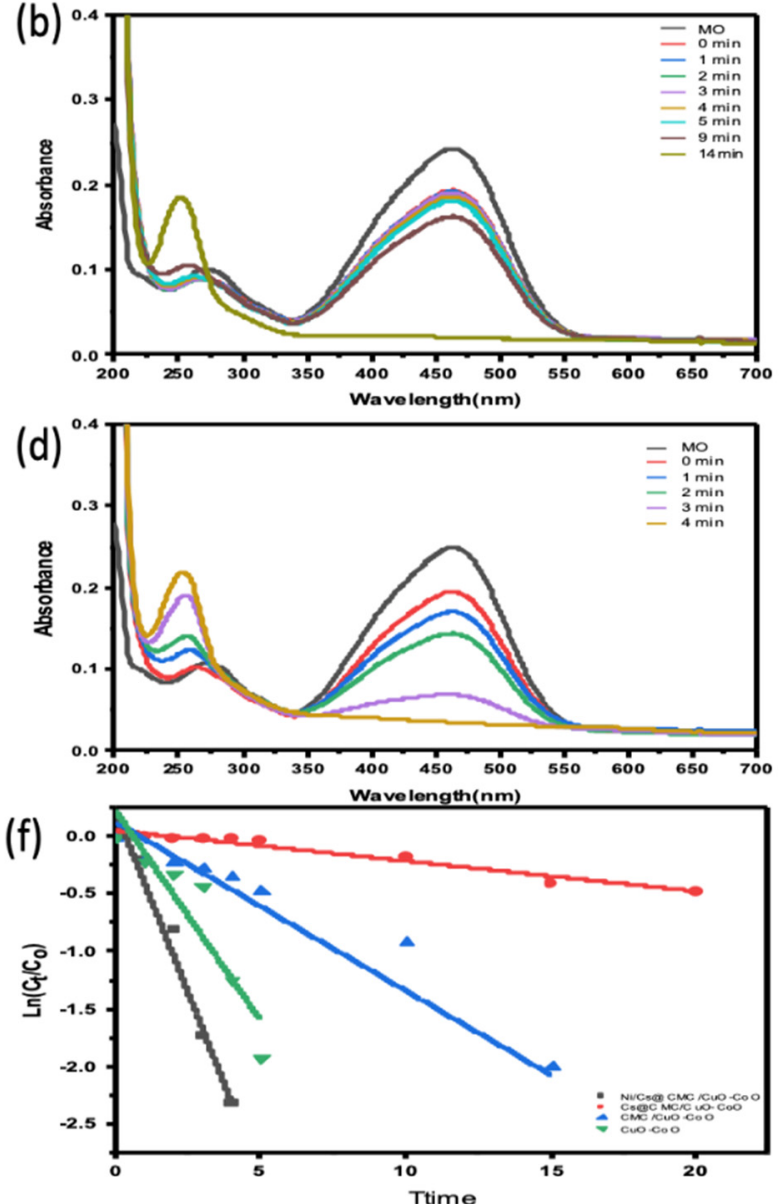

Figure 8. Catalytic activity for the reduction of $\mathrm{MO}$ degradation with $5 \mathrm{mg}$ of different catalysts: (a) $\mathrm{CuO}-\mathrm{Co}_{2} \mathrm{O}_{3}$, (b) $\mathrm{CMC} / \mathrm{CuO}-\mathrm{Co}_{2} \mathrm{O}_{3}$, (c) $\mathrm{Cs} @ \mathrm{CMC} / \mathrm{CuO}-\mathrm{Co}_{2} \mathrm{O}_{3}$, (d) Ni/Cs@CMC $/ \mathrm{CuO}-\mathrm{Co}_{2} \mathrm{O}_{3}$ and (e) $\mathrm{Ag} / \mathrm{CMC} / \mathrm{CuO}-\mathrm{Co}_{2} \mathrm{O}_{3}$. (f) $\ln (\mathrm{Ct} / \mathrm{Co})$ versus time for the transformation of $\mathrm{MO}$ using prepared catalysts. 
The kinetic behavior of four prepared catalysts toward the reduction of MO dye was evaluated by applying the pseudo-first-order kinetics. The rate constants were calculated from the slope of $\ln C_{t} / C_{0}$ vs. time, as seen in Figure $8 \mathrm{f}$. The rate constant $K$ value per second and $\mathrm{R}^{2}$ correlation coefficient of decolorization of $\mathrm{MO}$ dye with $\mathrm{Ni} / \mathrm{Cs} @ \mathrm{CMC} / \mathrm{CuO}-\mathrm{Co}_{2} \mathrm{O}_{3}$ was $1.02 \times 10^{-2} \mathrm{~s}^{-1}$ and 0.964 , respectively, which is higher than other catalysts, using $\mathrm{Cs} @ \mathrm{CMC} / \mathrm{CuO}-\mathrm{Co}_{2} \mathrm{O}_{3}\left(4.4 \times 10^{-4}\right.$ and 0.953), $\mathrm{CMC} / \mathrm{CuO}-\mathrm{Co}_{2} \mathrm{O}_{3}\left(2.6 \times 10^{-3}\right.$ and 0.915) and $\mathrm{CuO}-\mathrm{Co}_{2} \mathrm{O}_{3}\left(6.11 \times 10^{-3}\right.$ and 0.868). This clearly indicates that Ni/Cs@CMC/CuO$\mathrm{Co}_{2} \mathrm{O}_{3}$ is the most active catalyst among other prepared catalysts toward the reduction of MO dye.

Moreover, the catalytic reduction was tested toward the degradation of EY. The decolorization of EY was conducted by using the same procedure described previously for catalytic reduction of MO (Figure 9). EY had an absorbance band at $510 \mathrm{~nm}$, which gradually decreased. During the reduction, the EY color changed from orange to pale yellow and then turned to colorless, indicating the formation of $\mathrm{ESH}_{2}$ [59]. Ni/Cs@ $\mathrm{CMC} / \mathrm{CuO}-\mathrm{Co}_{2} \mathrm{O}_{3}$ was the highest efficient catalyst toward EY. According to data obtained, around $90 \%$ of EY was decolorized in $9 \mathrm{~min}$ by $\mathrm{Ni} / \mathrm{Cs} @ \mathrm{CMC} / \mathrm{CuO}-\mathrm{Co}_{2} \mathrm{O}_{3}$, while reduction of $71 \%, 94 \%$ and $35 \%$ were obtained in 24, 15 and 25 min with $\mathrm{Cs} @ \mathrm{CMC} / \mathrm{CuO}-\mathrm{Co}_{2} \mathrm{O}_{3}, \mathrm{CMC} / \mathrm{CuO}-\mathrm{Co}_{2} \mathrm{O}_{3}$ and $\mathrm{CuO}-\mathrm{Co}_{2} \mathrm{O}_{3}$, respectively. The rate constant and $\mathrm{R}^{2}$ were found to be $4.58 \times 10^{-3}$ and $0.936,7.71 \times 10^{-4}$ and $0.968,3.2 \times 10^{-3}$ and 0.928 and $2.95 \times 10^{-4}$ and 0.989 for $\mathrm{Ni} / \mathrm{Cs} @ \mathrm{CMC} / \mathrm{CuO}-\mathrm{Co}_{2} \mathrm{O}_{3}, \mathrm{Cs} @ \mathrm{CMC} / \mathrm{CuO}-\mathrm{Co}_{2} \mathrm{O}_{3}, \mathrm{CMC} / \mathrm{CuO}-\mathrm{Co}_{2} \mathrm{O}_{3}$ and $\mathrm{CuO}-\mathrm{Co}_{2} \mathrm{O}_{3}$, respectively (Table 6). Among all prepared catalysts, $\mathrm{Ni} / \mathrm{Cs} @ \mathrm{CMC} / \mathrm{CuO}-\mathrm{Co}_{2} \mathrm{O}_{3}$ is the most active catalyst toward EY dye. The catalytic activity of the $\mathrm{Ni} / \mathrm{Cs} @ \mathrm{CMC} / \mathrm{CuO}-\mathrm{Co}_{2} \mathrm{O}_{3}$ toward $\mathrm{MO}$ and $\mathrm{EY}$ was compared with other reported catalysts in the literature, as illustrated in Table 7.
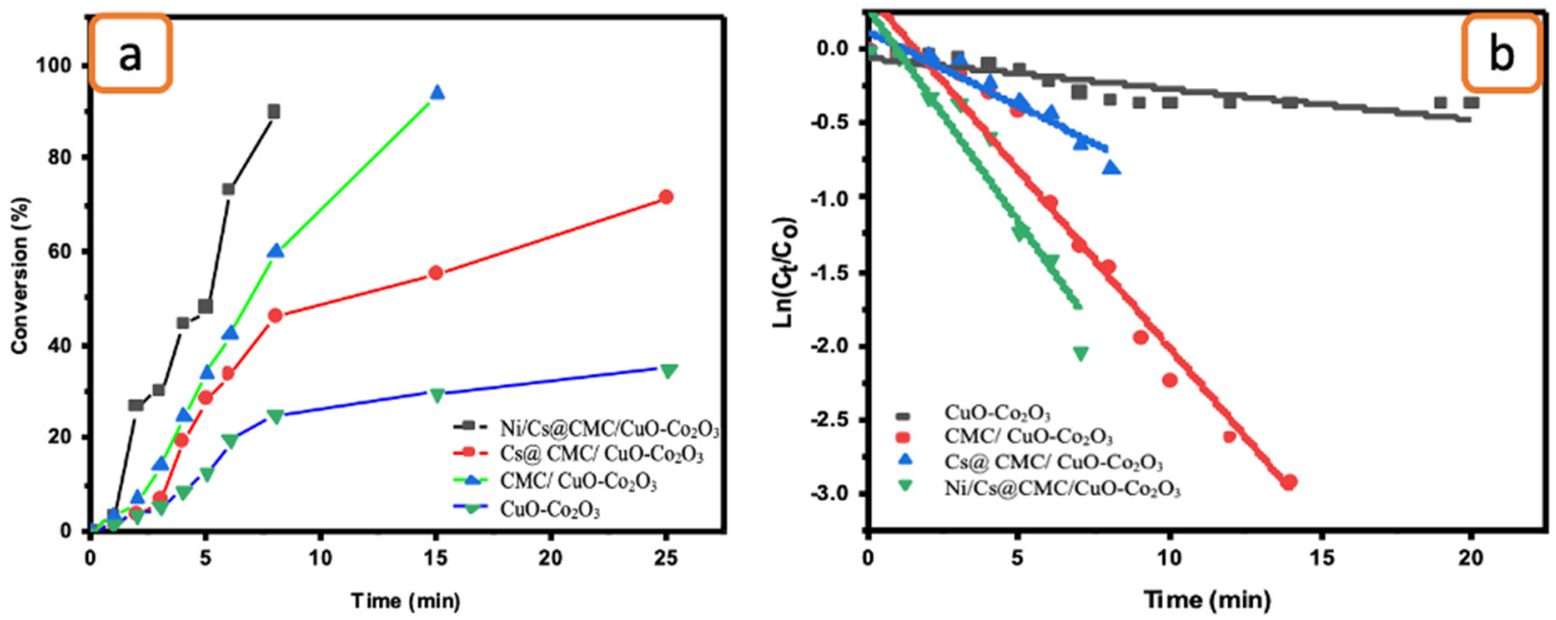

Figure 9. (a) Conversion versus time for the reduction of EY by the prepared catalysts. $(\mathbf{b}) \ln \left(C_{t} / C_{0}\right)$ vs. time for the transformation of EY by the prepared catalysts.

Table 6. Rate constant and $\mathrm{R}^{2}$ for the degradation of EY and MO and reduction of 4-NP and $\mathrm{K}_{3}\left[\mathrm{Fe}(\mathrm{CN})_{6}\right]$.

\begin{tabular}{|c|c|c|c|c|}
\hline \multirow[b]{2}{*}{ Compound } & \multicolumn{4}{|c|}{ Rate Constant $\mathrm{K}\left(\mathrm{s}^{-1}\right)$ and Adjacent $\mathrm{R}^{2}$ Value } \\
\hline & $\mathrm{CuO}-\mathrm{Co}_{2} \mathrm{O}_{3}$ & $\mathrm{CMC} / \mathrm{CuO}-\mathrm{Co}_{2} \mathrm{O}_{3}$ & $\mathrm{Cs} @ \mathrm{CMC} / \mathrm{CuO}-\mathrm{Co}_{2} \mathrm{O}_{3}$ & $\mathrm{Ni} / \mathrm{Cs} @ \mathrm{CMC} / \mathrm{CuO}-\mathrm{Co}_{2} \mathrm{O}_{3}$ \\
\hline $\mathrm{MO}$ & $6.11 \times 10^{-3}$ and 0.865 & $2.6 \times 10^{-3}$ and 0.915 & $4.4 \times 10^{-4}$ and 0.953 & $1.06 \times 10^{-2}$ and 0.964 \\
\hline EY & $2.95 \times 10^{-4}$ and 0.989 & $3.2 \times 10^{-3}$ and 0.928 & $7.71 \times 10^{-4}$ and 0.968 & $4.58 \times 10^{-3}$ and 0.936 \\
\hline 4-NP & $2.7 \times 10^{-3}$ and 0.855 & $2.62 \times 10^{-3}$ and 0.842 & $1.7 \times 10^{-5}$ and 0.824 & $4.26 \times 10^{-3}$ and 0.912 \\
\hline $\mathrm{K}_{3}\left[\mathrm{Fe}(\mathrm{CN})_{6}\right]$ & $3.6 \times 10^{-3}$ and 0.964 & $1.69 \times 10^{-3}$ and 0.835 & $1.8 \times 10^{-3}$ and 0.909 & $5.1 \times 10^{-3}$ and 0.975 \\
\hline
\end{tabular}


Table 7. Comparison of Ni/Cs@CMC /CuO- $\mathrm{Co}_{2} \mathrm{O}_{3}$ catalyst toward the reduction of MO, EY, 4-NP and $\mathrm{K}_{3}\left[\mathrm{Fe}(\mathrm{CN})_{6}\right]$ with other reported catalysts.

\begin{tabular}{|c|c|c|c|c|}
\hline Pollutant & Catalyst & $\begin{array}{l}\text { Time } \\
\text { (min) }\end{array}$ & $\begin{array}{c}\text { Rate } \\
\text { Constant }\end{array}$ & Ref. \\
\hline $\mathrm{MO}$ & $\mathrm{Ni} / \mathrm{Cs} @ \mathrm{CMC} / \mathrm{CuO}-\mathrm{Co}_{2} \mathrm{O}_{3}$ & 2 & $1.06 \times 10^{-2}$ & This study \\
\hline $\mathrm{MO}$ & TO-CoNPs & 60 & - & [60] \\
\hline $\mathrm{MO}$ & AuNPs & 8 & $1.7 \times 10^{-3}$ & [61] \\
\hline $\mathrm{MO}$ & WBs loaded with Ni NPs & 15 & $2.37 \times 10^{-3}$ & [62] \\
\hline EY & $\mathrm{Ni} / \mathrm{Cs} @ \mathrm{CMC} / \mathrm{CuO}-\mathrm{Co}_{2} \mathrm{O}_{3}$ & 6 & $4.58 \times 10^{-3}$ & This study \\
\hline EY & Chitosan-capped AuNPs & 50 & - & [63] \\
\hline $4-\mathrm{NP}$ & $\mathrm{Ni} / \mathrm{Cs} @ \mathrm{CMC} / \mathrm{CuO}-\mathrm{Co}_{2} \mathrm{O}_{3}$ & 13 & $4.26 \times 10^{-3}$ & This study \\
\hline $4-\mathrm{NP}$ & CMC-Cu & 35 & $9.1 \times 10^{-4}$ & [64] \\
\hline $4-\mathrm{NP}$ & PdNPs doped chitosan & 15 & $3.63 \times 10^{-3}$ & [65] \\
\hline 4-NP & $\mathrm{Ni} / \mathrm{CS}-\mathrm{FP}$ & 28 & - & [66] \\
\hline $\mathrm{K}_{3}\left[\mathrm{Fe}(\mathrm{CN})_{6}\right]$ & $\mathrm{Ni} / \mathrm{Cs} @ \mathrm{CMC} / \mathrm{CuO}-\mathrm{Co}_{2} \mathrm{O}_{3}$ & 6 & $5.1 \times 10^{-3}$ & This study \\
\hline $\mathrm{K}_{3}\left[\mathrm{Fe}(\mathrm{CN})_{6}\right]$ & $\mathrm{NiWO}_{4}$ Nanoparticles & 240 & - & [67] \\
\hline $\mathrm{K}_{3}\left[\mathrm{Fe}(\mathrm{CN})_{6}\right]$ & $\mathrm{Fe}_{3} \mathrm{O}_{4}-\mathrm{CuAg} \mathrm{NPs}$ & 3 & $19.3 \times 10^{-3}$ & [68] \\
\hline $\mathrm{K}_{3}\left[\mathrm{Fe}(\mathrm{CN})_{6}\right]$ & $\mathrm{CMC} / \mathrm{CuO}-\mathrm{NiO}$ & 0.5 & $6.88 \times 10^{-2}$ & {$[4]$} \\
\hline
\end{tabular}

Figure 10 shows the possible reduction mechanism of MO and EY. The reduction occurs mainly through the transfer of electrons via nanocatalyst facilitation. Firstly, the $\mathrm{NaBH}_{4}$ dissociates to $\mathrm{BH}_{4}{ }^{-}$ions and $\mathrm{Na}^{+}$, in which $\mathrm{BH}_{4}{ }^{-}$acts as a source of $\mathrm{e}^{-}$and $\mathrm{H}^{+}$. Further, the catalyst Ni/Cs@CMC/CuO- $\mathrm{Co}_{2} \mathrm{O}_{3}$ transfers $\mathrm{e}^{-}$from the $\mathrm{BH}_{4}{ }^{-}$ion to dye molecules for catalytic reduction. For $\mathrm{MO}$ dye, the azo bonds are activated by the electron transfers by $\mathrm{BH}_{4}{ }^{-}$ion via $\mathrm{Ni} / \mathrm{Cs} @ \mathrm{CMC} / \mathrm{CuO}-\mathrm{Co}_{2} \mathrm{O}_{3}$ nanocomposite beads. The $\mathrm{MO}$ molecules are bounded to the nanocomposite beads by oxygen and sulfur atoms. Thus, the first step is the conversion of the $-\mathrm{N}=\mathrm{N}-$ bond into $-\mathrm{HN}-\mathrm{NH}-$ bond followed by bond-breaking to form aromatic amines. In fact, this happens because $\mathrm{e}^{-}$are accepted from nanocomposite beads catalyst and $\mathrm{H}^{+}$from $\mathrm{BH}_{4}{ }^{-}$. Thus, the orange color of the $\mathrm{MO}$ dye is turned colorless, indicating the completion of the reduction of $\mathrm{MO}$. On the other hand, the $\mathrm{EY}$ is adsorbed on the surface of $\mathrm{Ni} / \mathrm{Cs} @ \mathrm{CMC} / \mathrm{CuO}-\mathrm{Co}_{2} \mathrm{O}_{3}$ nanocomposite beads because of the electrostatic attractive force between $\mathrm{Ni} / \mathrm{Cs} @ \mathrm{CMC} / \mathrm{CuO}-\mathrm{Co}_{2} \mathrm{O}_{3}$ nanocomposite and anionic dye. Afterward, the electron is transferred by Ni/Cs@CMC/CuO- $\mathrm{Co}_{2} \mathrm{O}_{3}$ from $\mathrm{BH}_{4}{ }^{-}$to EY for its catalytic reduction [4].

Additionally, an evaluation of $\mathrm{CuO}-\mathrm{Co}_{2} \mathrm{O}_{3}, \mathrm{CMC} / \mathrm{CuO}-\mathrm{Co}_{2} \mathrm{O}_{3}, \mathrm{Cs} @ \mathrm{CMC} / \mathrm{CuO}-\mathrm{Co}_{2} \mathrm{O}_{3}$ and $\mathrm{Ni} / \mathrm{Cs} @ \mathrm{CMC} / \mathrm{CuO}-\mathrm{Co}_{2} \mathrm{O}_{3}$ as catalysts toward the catalytic reduction of 4-NP was performed. By using the same procedure mentioned previously, the reaction of 4-NP was performed by utilizing $\mathrm{CuO}-\mathrm{Co}_{2} \mathrm{O}_{3}, \mathrm{CMC} / \mathrm{CuO}-\mathrm{Co}_{2} \mathrm{O}_{3}, \mathrm{Cs} @ \mathrm{CMC} / \mathrm{CuO}-\mathrm{Co}_{2} \mathrm{O}_{3}$ and $\mathrm{Ni} / \mathrm{Cs} @ \mathrm{CMC} / \mathrm{CuO}-\mathrm{Co}_{2} \mathrm{O}_{3}$ as catalysts in the presence of $\mathrm{NaBH}_{4}$. In the beginning, the absorbance band of 4-NP appeared at $\lambda_{\max }=317 \mathrm{~nm}$. As observed, the yellow color of 4-NP changed directly to dark yellow in the presence of $(0.5 \mathrm{~mL}) \mathrm{NaBH}_{4}$ with a new UV-Vis band appearing at $400 \mathrm{~nm}$. This indicates the transformation of 4-NP to 4-nitrophenolate. Then, the $\mathrm{CuO}-\mathrm{Co}_{2} \mathrm{O}_{3}, \mathrm{CMC} / \mathrm{CuO}-\mathrm{Co}_{2} \mathrm{O}_{3}, \mathrm{Cs} @ \mathrm{CMC} / \mathrm{CuO}-\mathrm{Co}_{2} \mathrm{O}_{3}$ and $\mathrm{Ni} / \mathrm{Cs} @ \mathrm{CMC} / \mathrm{CuO}$ $\mathrm{Co}_{2} \mathrm{O}_{3}$ catalysts were added and tested separately for the reduction of 4-nitrophenol. The band at $\lambda_{\max }=400 \mathrm{~nm}$ disappeared gradually, and a new absorbance band at $\lambda_{\max }=320 \mathrm{~nm}$ appeared along with the disappearance of dark yellow color, proving the formation of 4-AP because of 4-NP reduction. It was found that among all the catalysts, the prepared $\mathrm{Ni} / \mathrm{Cs} @ \mathrm{CMC} / \mathrm{CuO}-\mathrm{Co}_{2} \mathrm{O}_{3}$ was the most effective catalyst because 4-NP was completely reduced to 4-AP in $13 \mathrm{~min}$, while it was reduced in 19 and $20 \mathrm{~min}$ by using $\mathrm{CuO}-\mathrm{Co}_{2} \mathrm{O}_{3}$ and $\mathrm{CMC} / \mathrm{CuO}-\mathrm{Co}_{2} \mathrm{O}_{3}$, respectively. However, the reduction of 4-NP by Cs@CMC/CuO- $-\mathrm{Co}_{2} \mathrm{O}_{3}$ took 20 min (Figure 11a). 


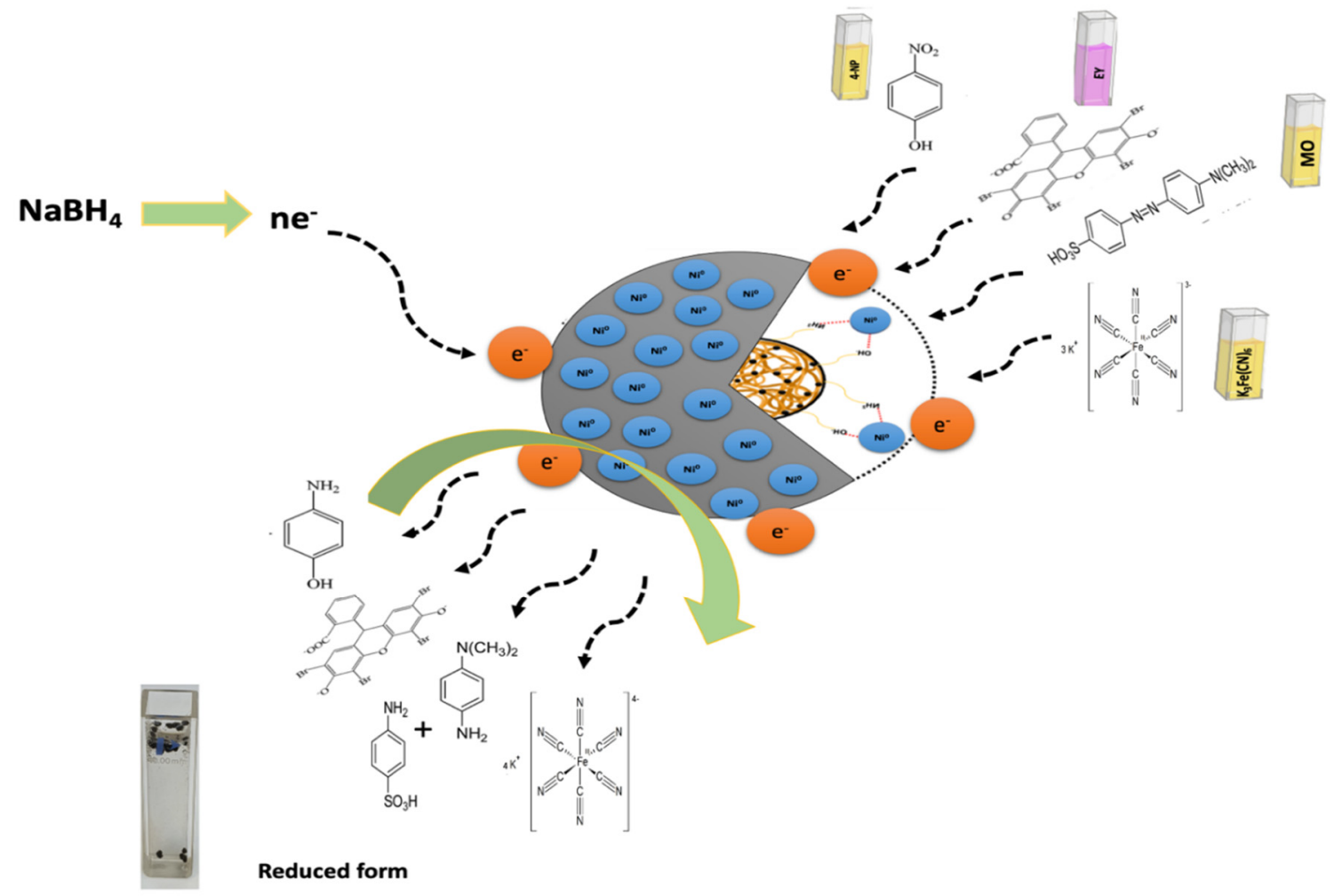

Figure 10. Mechanism for catalytic reduction of target pollutants (4-NP, $\mathrm{K}_{3}\left[\mathrm{Fe}(\mathrm{CN})_{6}\right], \mathrm{MO}$ and $\left.\mathrm{EY}\right)$.
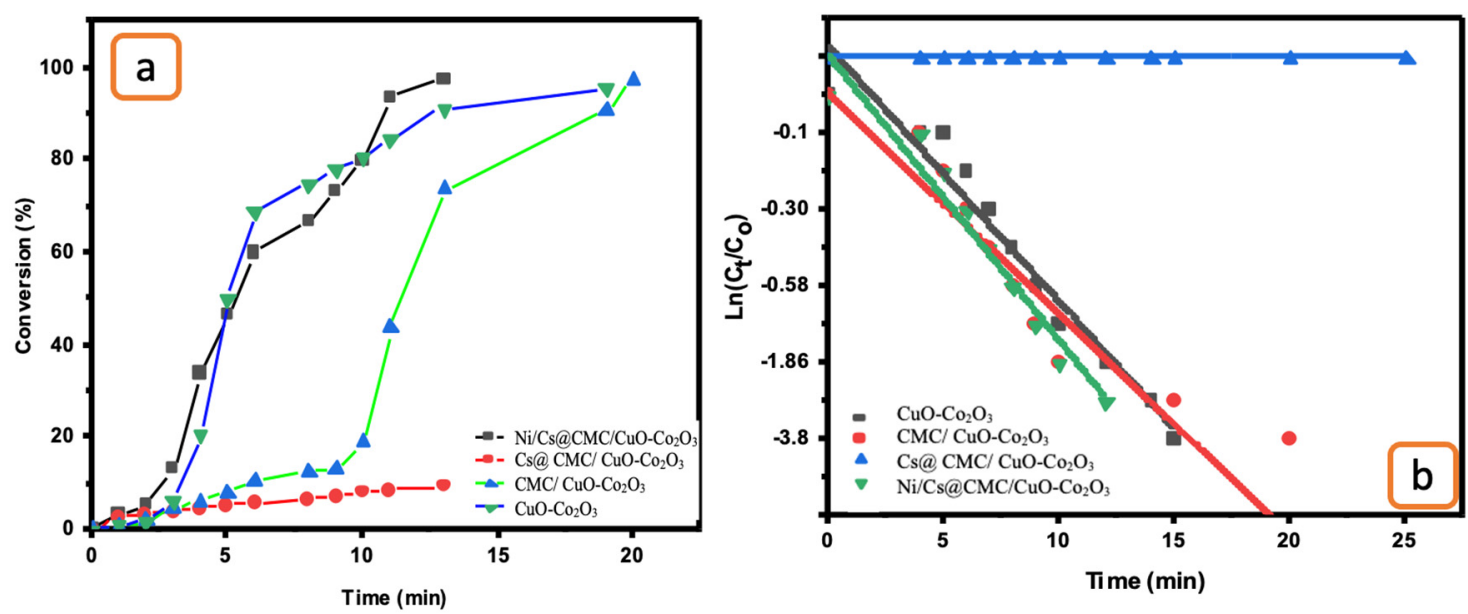

Figure 11. (a) Conversion versus time for the reduction of $4-N P$ by the prepared catalysts. $(b) \ln \left(C_{t} / C_{o}\right)$ vs. time for the transformation of $4-\mathrm{NP}$ by the prepared catalysts.

The rate constant and $\mathrm{R}^{2}$ were found to be $4.26 \times 10^{-3} \mathrm{~s}^{-1}$ and $0.912,17 \times 10^{-5} \mathrm{~s}^{-1}$ and $0.824,2.62 \times 10^{-3} \mathrm{~s}^{-1}$ and 0.842 and $2.7 \times 10^{-3} \mathrm{~s}^{-1}$ and 0.855 for Ni/Cs@CMC/CuO$\mathrm{Co}_{2} \mathrm{O}_{3}, \mathrm{Cs} @ \mathrm{CMC} / \mathrm{CuO}-\mathrm{Co}_{2} \mathrm{O}_{3}, \mathrm{CMC} / \mathrm{CuO}-\mathrm{Co}_{2} \mathrm{O}_{3}$ and $\mathrm{CuO}-\mathrm{Co}_{2} \mathrm{O}_{3}$, respectively, as shown in Table 6 and Figure 11b. The data for 4-NP reduction was compared with other catalysts and is illustrated in Table 7.

The catalytic reduction of $\mathrm{K}_{3}\left[\mathrm{Fe}(\mathrm{CN})_{6}\right]$ was also examined to evaluate the catalytic activity of $\mathrm{CuO}-\mathrm{Co}_{2} \mathrm{O}_{3}, \mathrm{CMC} / \mathrm{CuO}-\mathrm{Co}_{2} \mathrm{O}_{3}, \mathrm{Cs} @ \mathrm{CMC} / \mathrm{CuO}-\mathrm{Co}_{2} \mathrm{O}_{3}$ and $\mathrm{Ni} / \mathrm{Cs} @ \mathrm{CMC} / \mathrm{CuO}-$ $\mathrm{Co}_{2} \mathrm{O}_{3}$. The UV-vis absorption of the catalytic reduction of $\mathrm{K}_{3}\left[\mathrm{Fe}(\mathrm{CN})_{6}\right]$ was monitored every minute to check the progress of the $\mathrm{K}_{3}\left[\mathrm{Fe}(\mathrm{CN})_{6}\right]$ reduction. As the catalytic reaction proceeded in the presence of $\mathrm{NaBH}_{4}$ and the catalyst, the absorption band of $\mathrm{K}_{3}\left[\mathrm{Fe}(\mathrm{CN})_{6}\right]$ at $\lambda_{\max }=420 \mathrm{~nm}$ gradually decreased in $6 \mathrm{~min}$ when using $\mathrm{Ni} / \mathrm{Cs} @ \mathrm{CMC} / \mathrm{CuO}-\mathrm{Co}_{2} \mathrm{O}_{3}$ along with disappearance of the yellow color, indicating the reduction of $\mathrm{K}_{3}\left[\mathrm{Fe}(\mathrm{CN})_{6}\right]$ 
to $\mathrm{K}_{4}\left[\mathrm{Fe}(\mathrm{CN})_{6}\right]$ [69]. In contrast, the reduction reaction took longer times of 8,13 and 18 min when using $\mathrm{CuO}-\mathrm{Co}_{2} \mathrm{O}_{3}, \mathrm{CMC} / \mathrm{CuO}-\mathrm{Co}_{2} \mathrm{O}_{3}$ and $\mathrm{Cs} @ \mathrm{CMC} / \mathrm{CuO}-\mathrm{Co}_{2} \mathrm{O}_{3}$, respectively. The efficient transformation of $\mathrm{K}_{3}\left[\mathrm{Fe}(\mathrm{CN})_{6}\right]$ to $\mathrm{K}_{4}\left[\mathrm{Fe}(\mathrm{CN})_{6}\right]$ was obtained by applying the $\mathrm{Ni} / \mathrm{Cs} @ \mathrm{CMC} / \mathrm{CuO}-\mathrm{Co}_{2} \mathrm{O}_{3}$ catalyst (91\%), while 85, 73.5 and 83\% reduction were obtained by using $\mathrm{Cs} @ \mathrm{CMC} / \mathrm{CuO}-\mathrm{Co}_{2} \mathrm{O}_{3}, \mathrm{CMC} / \mathrm{CuO}-\mathrm{Co}_{2} \mathrm{O}_{3}$ and $\mathrm{CuO}-\mathrm{Co}_{2} \mathrm{O}_{3}$, as shown in Figure 12a. Based on findings, the catalytic reduction reaction of $\mathrm{K}_{3}\left[\mathrm{Fe}(\mathrm{CN})_{6}\right]$ follows the pseudo-first-order, as seen in Figure $12 \mathrm{~b}$. Subsequently, the rate constant and $\mathrm{R}^{2}$ were found to be $5.1 \times 10^{-3} \mathrm{~s}^{-1}$ and $0.975,1.8 \times 10^{-3} \mathrm{~s}^{-1}$ and $0.909,1.69 \times 10^{-3} \mathrm{~s}^{-1}$ and 0.835 and $3.6 \times 10^{-3} \mathrm{~s}^{-1}$ and 0.964 for $\mathrm{Ni} / \mathrm{Cs} @ \mathrm{CMC} / \mathrm{CuO}-\mathrm{Co}_{2} \mathrm{O}_{3}, \mathrm{Cs} @ \mathrm{CMC} / \mathrm{CuO}-\mathrm{Co}_{2} \mathrm{O}_{3}$, $\mathrm{CMC} / \mathrm{CuO}-\mathrm{Co}_{2} \mathrm{O}_{3}$ and $\mathrm{CuO}-\mathrm{Co}_{2} \mathrm{O}_{3}$, respectively, as shown in Table 6.
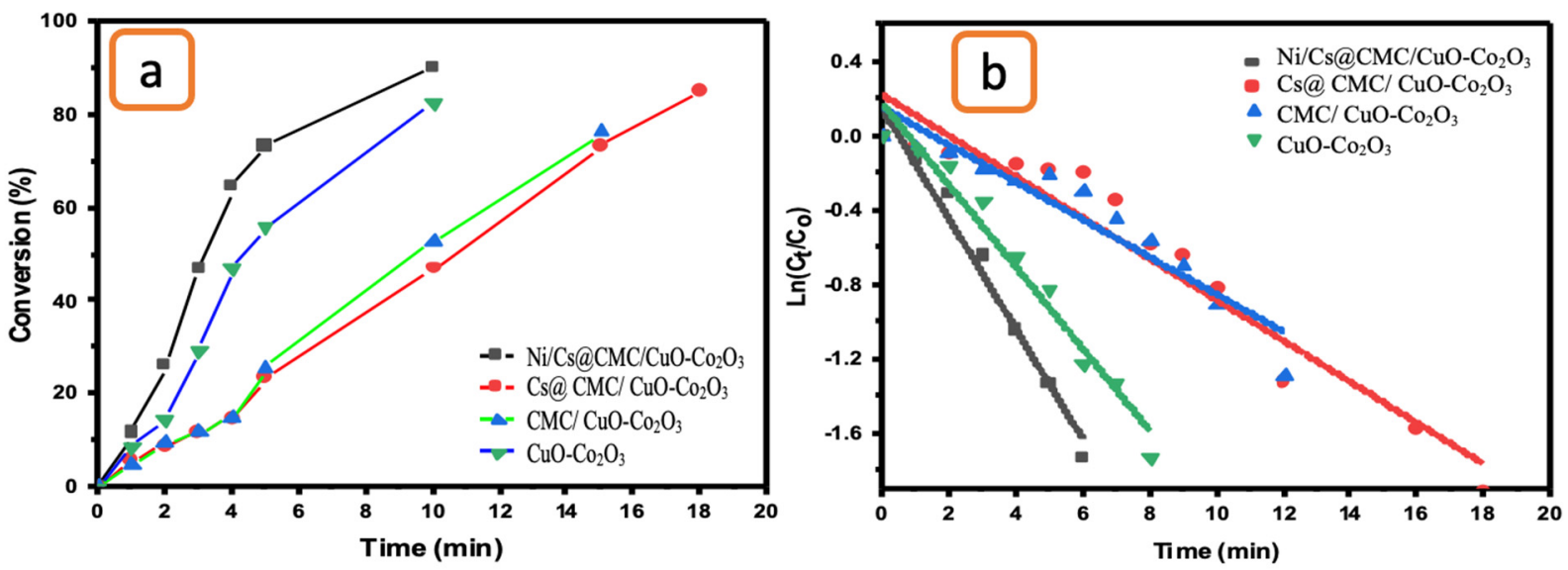

Figure 12. (a) Conversion versus time for the reduction of $\mathrm{K}_{3}\left[\mathrm{Fe}(\mathrm{CN})_{6}\right]$ by the prepared catalysts. (b) $\ln \left(\mathrm{C}_{\mathrm{t}} / \mathrm{C}_{\mathrm{o}}\right)$ vs. time for the transformation of $\mathrm{K}_{3}\left[\mathrm{Fe}(\mathrm{CN})_{6}\right]$ by the prepared catalysts.

The possible mechanism for the reaction of $\mathrm{K}_{3}\left[\mathrm{Fe}(\mathrm{CN})_{6}\right]$ in the presence of both catalyst beads and $\mathrm{NaBH}_{4}$ is illustrated in Figure 10. Based on the reported studies, the catalytic reduction of $\left[\mathrm{Fe}(\mathrm{CN})_{6}\right]^{-3}$ to form $\left[\mathrm{Fe}(\mathrm{CN})_{6}\right]^{-4}$ is an electron-transfer route, as shown in the reaction below [3]. Therefore, the catalytic reaction mechanism of $\mathrm{K}_{3}\left[\mathrm{Fe}(\mathrm{CN})_{6}\right]$ involves two main steps. Initially, polarization of the catalyst nanocomposite beads occurs by the reducing agent $\mathrm{NaBH}_{4}$. Afterward, $\mathrm{e}^{-}$are transferred from the catalyst surface to the $\left[\mathrm{Fe}(\mathrm{CN})_{6}\right]^{-3}$ and get reduced to $\left[\mathrm{Fe}(\mathrm{CN})_{6}\right]^{-4}$, as shown in Equation (8):

$\mathrm{BH}_{4}{ }^{-}(\mathrm{aq})+8\left[\mathrm{Fe}(\mathrm{CN})_{6}\right]^{3-}(\mathrm{aq})+3 \mathrm{H}_{2} \mathrm{O}(\mathrm{aq}) \rightarrow \mathrm{H}_{2} \mathrm{BO}_{3}{ }^{-}(\mathrm{aq})+8\left[\mathrm{Fe}(\mathrm{CN})_{6}\right]^{4-}(\mathrm{aq})+8 \mathrm{H}^{+}$

\subsection{Catalytic Optimization}

\subsubsection{Effect of Contaminant Concentrations}

The effect of concentration was examined for all compounds (4-NP, EY, MO and $\left.\mathrm{K}_{3}\left[\mathrm{Fe}\left(\mathrm{CN}_{6}\right)\right]\right)$ by using a certain catalyst $\left(\mathrm{Ni} / \mathrm{Cs} @ \mathrm{CMC} / \mathrm{CuO}-\mathrm{Co}_{2} \mathrm{O}_{3}\right)$ since it is more effective than others $\left(\mathrm{Cs} @ \mathrm{CMC} / \mathrm{CuO}-\mathrm{Co}_{2} \mathrm{O}_{3}, \mathrm{Cs} @ \mathrm{CMC} / \mathrm{CuO}-\mathrm{Co}_{2} \mathrm{O}_{3}, \mathrm{CMC} / \mathrm{CuO}-\mathrm{Co}_{2} \mathrm{O}_{3}\right.$ and $\mathrm{CuO}-\mathrm{Co}_{2} \mathrm{O}_{3}$ ). As clearly seen in all figures below (Figure 13), when the concentration of pollutants was increased the time taken for reduction was increased. This finding indicates that the concentration of the pollutants has an essential role and $\mathrm{Ni} / \mathrm{Cs} @ \mathrm{CMC} / \mathrm{CuO}-\mathrm{Co}_{2} \mathrm{O}_{3}$ was found to be more efficient catalyst with a low concentration of MO, EY, 4-NP and $\mathrm{K}_{3}\left[\mathrm{Fe}(\mathrm{CN})_{6}\right]$, which was found to have similar effect as reported in literature [70]. 

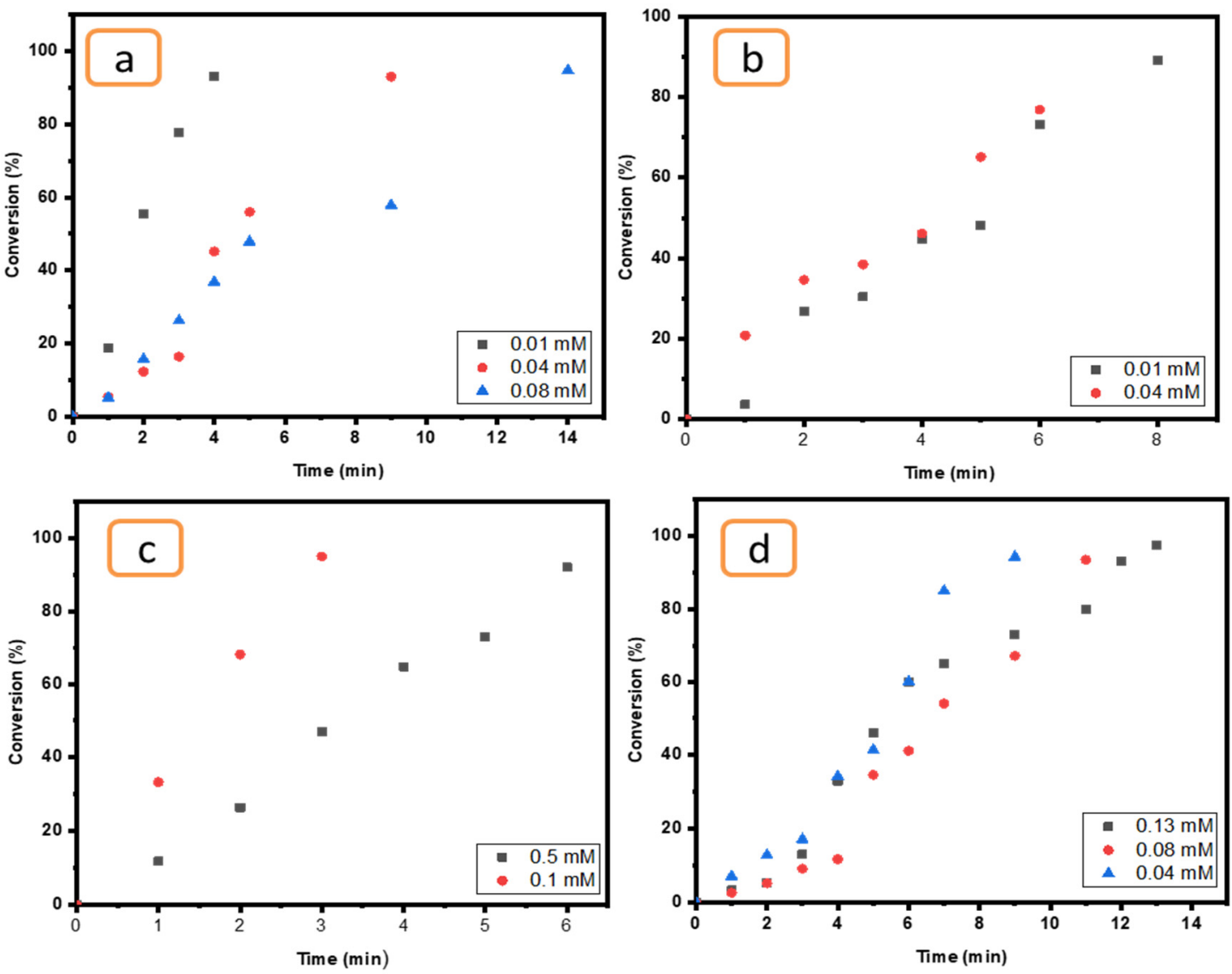

Figure 13. Effect of pollutants concentration for (a) $\mathrm{MO}(0.01,0.04$ and $0.08 \mathrm{mM}),(\mathbf{b}) \mathrm{EY}(0.01$ and $0.04 \mathrm{mM}),(\mathbf{c}) \mathrm{K}_{3}\left[\mathrm{Fe}(\mathrm{CN})_{6}\right](0.1$ and $0.5 \mathrm{mM})$ and $(\mathrm{d}) 4-\mathrm{NP}(0.04,0.08$ and $0.1 \mathrm{mM})$ reduction using $5 \mathrm{mg}$ of $\mathrm{Ni} / \mathrm{Cs} @ \mathrm{CMC} / \mathrm{CuO}-\mathrm{Co}_{2} \mathrm{O}_{3}$ beads.

\subsubsection{Effect of $\mathrm{NaBH}_{4}$ Concentration}

The impact of $\mathrm{NaBH}_{4}$ concentration on the catalytic reduction of pollutants is a very important parameter. Therefore, a range of $\mathrm{NaBH}_{4}$ concentrations $(0.2,0.1$ and $0.05 \mathrm{M})$ were used to evaluate its effect on the reduction of target pollutants in the presence of $\mathrm{Ni} / \mathrm{Cs} @ \mathrm{CMC} / \mathrm{CuO}-\mathrm{Co}_{2} \mathrm{O}_{3}$ beads as a catalyst. As the data demonstrate, the reducing agent has an important role in the reduction reaction of pollutants in the presence of an effective catalyst. However, this reducing agent has no activity or ability to reduce toxic compounds even at high concentrations. Therefore, an effective catalyst should be added to enhance the reduction. A high concentration of $\mathrm{NaBH}_{4}(0.2 \mathrm{M})$ in addition to an effective catalyst such as $\mathrm{Ni} / \mathrm{Cs} @ \mathrm{CMC} / \mathrm{CuO}-\mathrm{Co}_{2} \mathrm{O}_{3}$ can promote the reduction reaction of $\mathrm{MO}$ at a faster rate, decolorizing it in only $2 \mathrm{~min}$, as shown in Figure 14a. However, when the reducing agent $\left(\mathrm{NaBH}_{4}\right)$ concentration was decreased, the reduction reaction rate was influenced and decreased. This means that the reduction reaction requires more time to complete. Indeed, MO was reduced in $4 \mathrm{~min}$ and $12 \mathrm{~min}$ when the $\mathrm{NaBH}_{4}$ concentration was 0.1 and $0.05 \mathrm{M}$, respectively, as shown in Figure 14a. EY was also reduced in 6 min by using a high $\mathrm{NaBH}_{4}$ concentration, while this reduction took 9 min and 14 min using 0.1 and $0.05 \mathrm{M} \mathrm{NaBH}_{4}$, respectively, as shown in Figure 16b. The same effect was observed for $\mathrm{K}_{3}\left[\mathrm{Fe}(\mathrm{CN})_{6}\right]$ (Figure $14 \mathrm{c}$ ) and 4-NP (Figure 14d), and a similar impact was reported in literature [70]. 

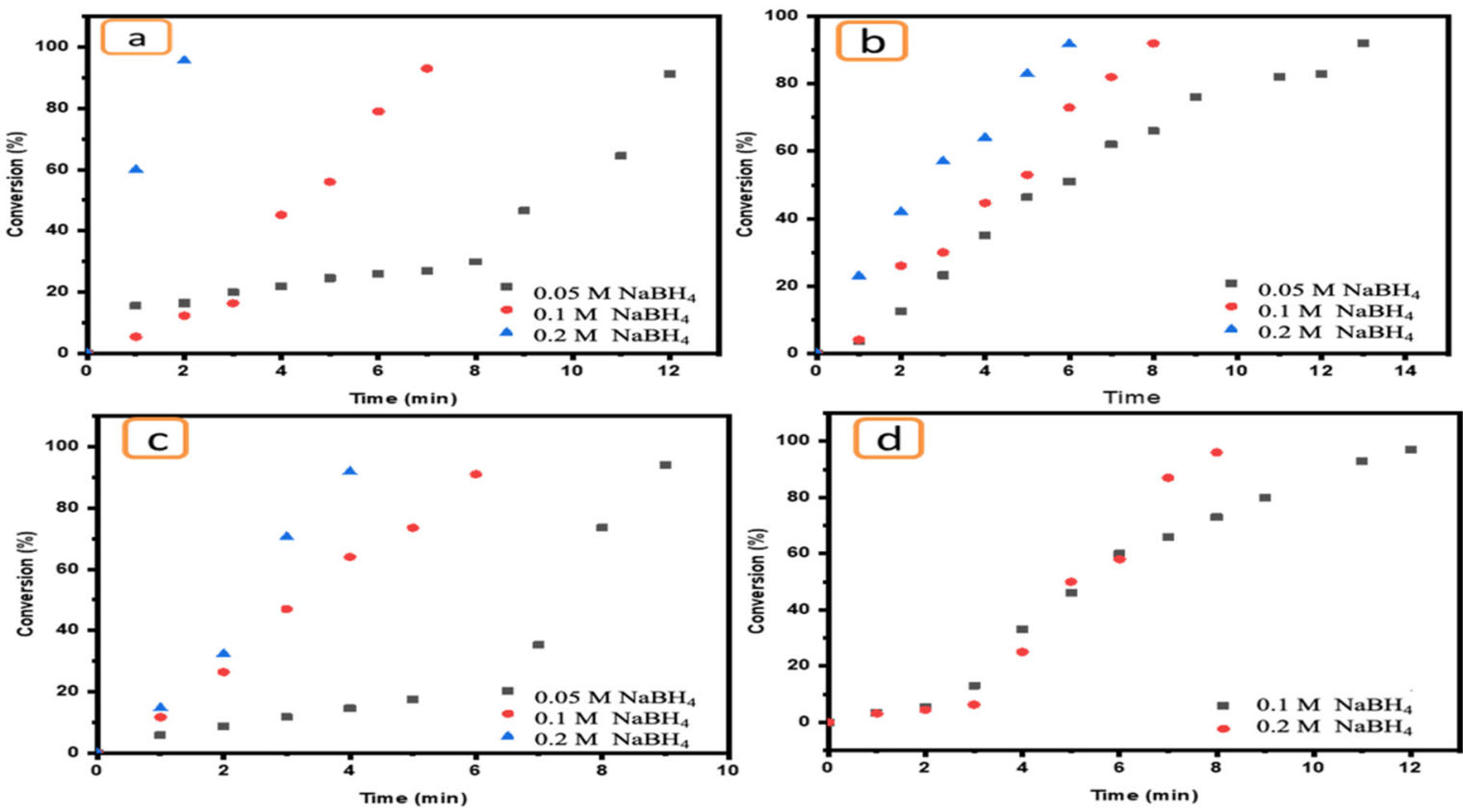

Figure 14. Effect of $\mathrm{NaBH}_{4}$ concentrations $(0.2,0.1$ and $0.05 \mathrm{M})$ on the reduction of (a) MO, (b) EY, (c) $\mathrm{K}_{3}\left[\mathrm{Fe}(\mathrm{CN})_{6}\right]$ and (d) 4-NP using $5 \mathrm{mg}$ of $\mathrm{Ni} / \mathrm{Cs} @ \mathrm{CMC} / \mathrm{CuO}-\mathrm{Co}_{2} \mathrm{O}_{3}$ beads.

\subsubsection{Effect of Number of $\mathrm{Ni} / \mathrm{Cs} @ \mathrm{CMC} / \mathrm{CuO}-\mathrm{Co}_{2} \mathrm{O}_{3}$ Beads}

The influence of amount of $\mathrm{Ni} / \mathrm{Cs} @ \mathrm{CMC} / \mathrm{CuO}-\mathrm{Co}_{2} \mathrm{O}_{3}$ was tested by utilizing three different amounts of $\mathrm{Ni} / \mathrm{Cs} @ \mathrm{CMC} / \mathrm{CuO}-\mathrm{Co}_{2} \mathrm{O}_{3}$ bead catalyst $(3 \mathrm{mg}, 5 \mathrm{mg}$ and $8 \mathrm{mg}$ ) in the presence of reducing agent $\left(0.2 \mathrm{M} \mathrm{NaBH}_{4}\right)$. This effect was tested using $0.01 \mathrm{mM} \mathrm{MO}$ and $0.05 \mathrm{mM} \mathrm{K}_{3}\left[\mathrm{Fe}\left(\mathrm{CN}_{6}\right)\right]$, as seen in Figure 15. In fact, the amount of catalyst is an important factor in the reduction reaction. The results demonstrate that a larger catalyst amount $(8 \mathrm{mg}$ of $\mathrm{Ni} / \mathrm{Cs} @ \mathrm{CMC} / \mathrm{CuO}-\mathrm{Co}_{2} \mathrm{O}_{3}$ ) could enhance the reaction of $\mathrm{MO}$ causing decolorization by $98 \%$ in 2 min and 92\% in 2 min using an amount of $5 \mathrm{mg}$. However, $\mathrm{MO}$ was reduced by $97 \%$ in 6 min by using a low amount of catalyst, as shown in Figure 15a. A similar effect was found for $\mathrm{K}_{3}\left[\mathrm{Fe}\left(\mathrm{CN}_{6}\right)\right]$, as clearly seen in Figure $15 \mathrm{~b}$.
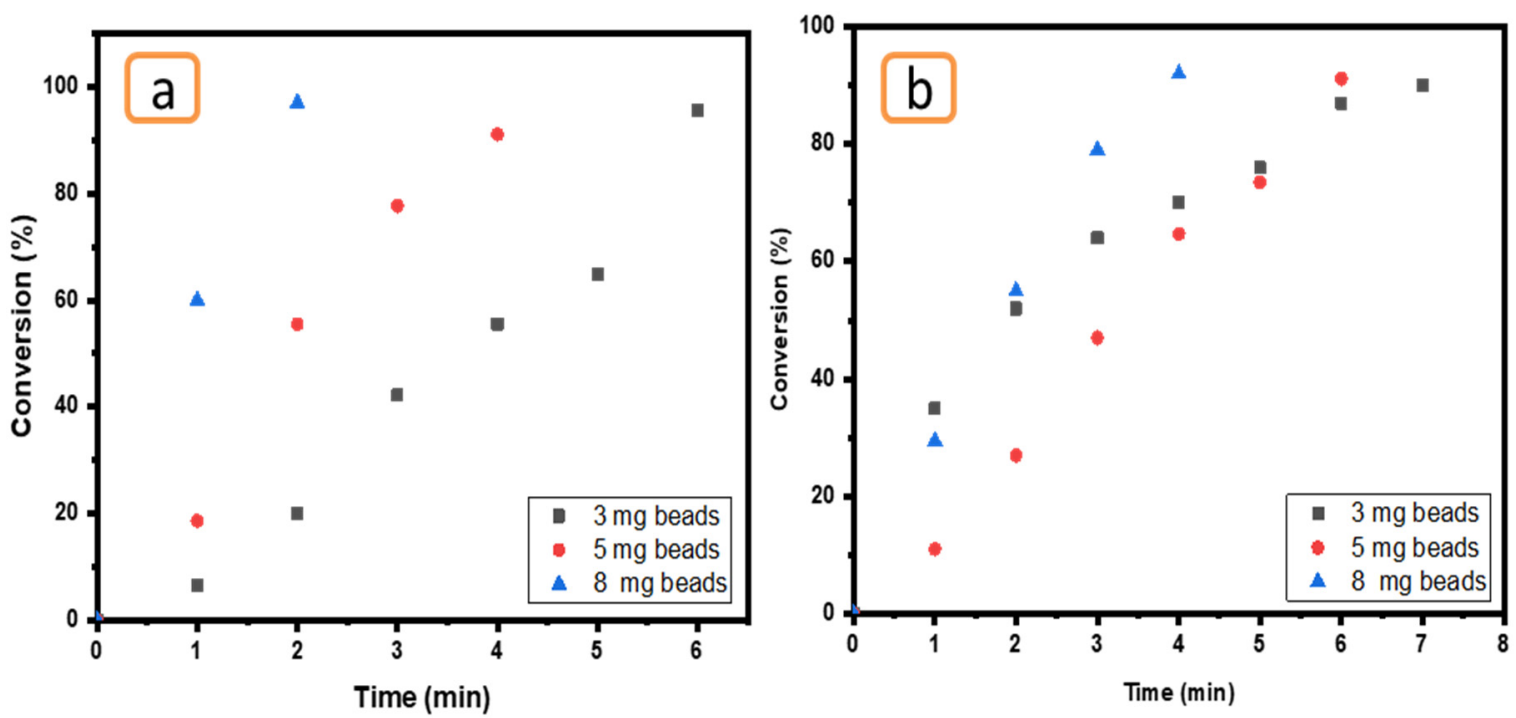

Figure 15. Effect of $\mathrm{Ni} / \mathrm{Cs} @ \mathrm{CMC} / \mathrm{CuO}-\mathrm{Co}_{2} \mathrm{O}_{3}$ beads amount $(3 \mathrm{mg}, 5 \mathrm{mg}$ and $8 \mathrm{mg}$ ) on the reduction of (a) $\mathrm{MO}$ and (b) $\mathrm{K}_{3}\left[\mathrm{Fe}\left(\mathrm{CN}_{6}\right)\right]$. 


\subsection{Recyclability of $\mathrm{Ni} / \mathrm{Cs} @ \mathrm{CMC} / \mathrm{CuO}-\mathrm{Co}_{2} \mathrm{O}_{3}$ Beads}

Recyclability of the catalyst is a significant factor during a catalytic reduction study. Most of the catalysts become deactivated after the first or second use. In our study, $\mathrm{Ni} / \mathrm{Cs} @ \mathrm{CMC} / \mathrm{CuO}-\mathrm{Co}_{2} \mathrm{O}_{3}$ was able to be reused up to five times without deactivation or any loss of the catalyst beads. Consequently, $\mathrm{Ni} / \mathrm{Cs} @ \mathrm{CMC} / \mathrm{CuO}-\mathrm{Co}_{2} \mathrm{O}_{3}$ beads were tested in the reduction of $\mathrm{MO}, \mathrm{EY}$ and $\mathrm{K}_{3}\left[\mathrm{Fe}(\mathrm{CN})_{6}\right]$ for several time to check the recyclability of the catalyst. As mentioned previously, the same procedures were followed, except the beads were washed by deionized water and then $\mathrm{MeOH}$, followed by deionized water several times, and then dried for the next use. This process was repeated five times to assess the reusability of the $\mathrm{Ni} / \mathrm{Cs} @ \mathrm{CMC} / \mathrm{CuO}-\mathrm{Co}_{2} \mathrm{O}_{3}$ beads. Figure 16 shows the time taken for each reduction cycle of $\mathrm{MO}, 4-\mathrm{NP}$ and $\mathrm{K}_{3}\left[\mathrm{Fe}(\mathrm{CN})_{6}\right]$ using $\mathrm{Ni} / \mathrm{Cs} @ \mathrm{CMC} / \mathrm{CuO}-\mathrm{Co}_{2} \mathrm{O}_{3}$ beads.

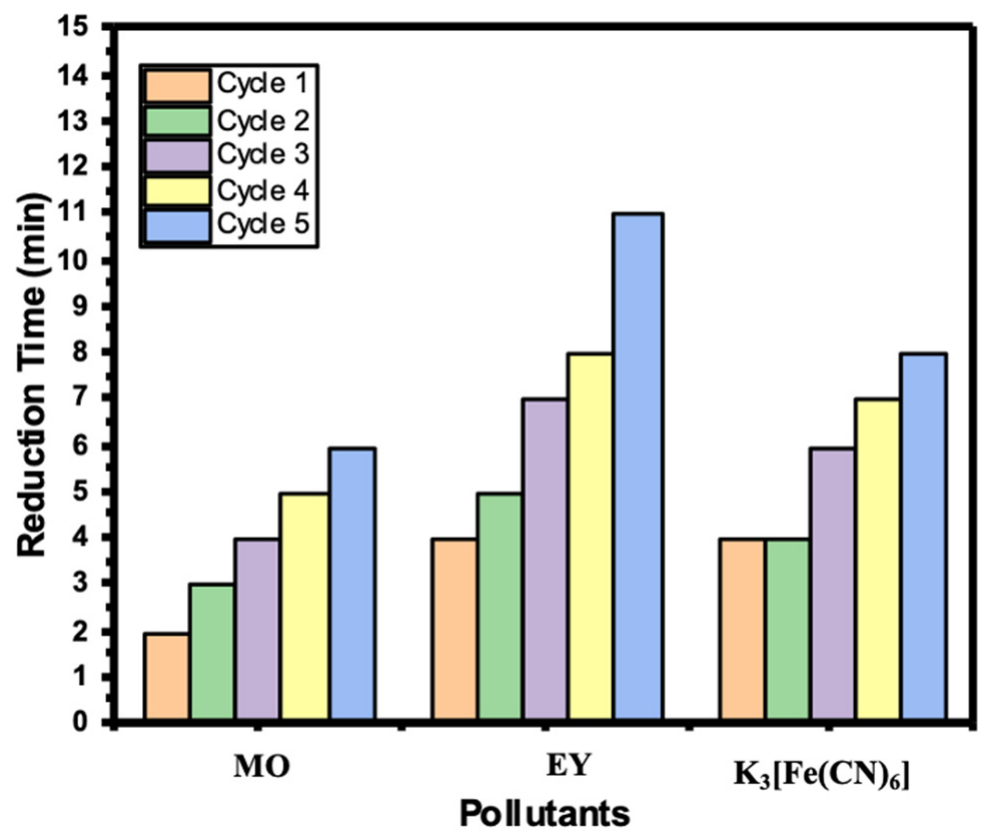

Figure 16. Recyclability of $\mathrm{Ni} / \mathrm{Cs} @ \mathrm{CMC} / \mathrm{CuO}-\mathrm{Co}_{2} \mathrm{O}_{3}$ beads toward the reduction of $\mathrm{MO}$, EY and $\mathrm{K}_{3}\left[\mathrm{Fe}\left(\mathrm{CN}_{6}\right)\right]$.

\subsection{Application to Real Samples}

The catalytic activity of $\mathrm{Ni} / \mathrm{Cs} @ \mathrm{CMC} / \mathrm{CuO}-\mathrm{Co}_{2} \mathrm{O}_{3}$ beads was also assessed in four types of real samples with spiked $\mathrm{MO}(0.06 \mathrm{mM})$. The real samples used for this study were full-fat milk and three juice samples (orange, pineapple and apple), and they were obtained from a local market (Jeddah, Saudi Arabia). The preparation of real samples was performed by taking around $1 \mathrm{~mL}$ of each sample and diluting it in $100 \mathrm{~mL}$ of deionized water individually. Further, $2.5 \mathrm{~mL}$ of each real sample was placed into a UV-vis cuvette, and $0.5 \mathrm{~mL}$ of $0.06 \mathrm{mM} \mathrm{MO}$ was added followed by addition of $0.5 \mathrm{~mL}$ of $0.1 \mathrm{M} \mathrm{NaBH}_{4}$. Finally, $5 \mathrm{mg}$ of $\mathrm{Ni} / \mathrm{Cs} @ \mathrm{CMC} / \mathrm{CuO}-\mathrm{Co}_{2} \mathrm{O}_{3}$ was added. The catalytic degradation of $\mathrm{MO}$ was monitored by a UV-vis spectrophotometer. As clearly seen from data presented in Table 8, full-fat milk was the only sample that took a longer time (15 $\mathrm{min})$ with a very low reduction $\%(65 \%)$. This is due to the high interference found in the milk, which can influence the reduction of MO. In contrast, the reduction of MO in the three juice samples occurred in 5-6 min with 91-97\%. The data confirm that the $\mathrm{Ni} / \mathrm{Cs} @ \mathrm{CMC} / \mathrm{CuO}$ $\mathrm{Co}_{2} \mathrm{O}_{3}$ is effective and reliable since it was able to decolorize and effectively reduce $\mathrm{MO}$ in real samples. 
Table 8. Application of four real samples spiked with MO.

\begin{tabular}{ccc}
\hline Real Sample & Reduction Time (min) & Reduction \% \\
\hline Full-Fat Milk & $15 \mathrm{~min}$ & 65.5 \\
Orange Juice & $6 \mathrm{~min}$ & 91.4 \\
Pineapple Juice & $5 \mathrm{~min}$ & 95 \\
Apple Juice & $5 \mathrm{~min}$ & 97 \\
\hline
\end{tabular}

\section{Conclusions}

$\mathrm{CuO}-\mathrm{Co}_{2} \mathrm{O}_{3}$ was synthesized, mixed with $\mathrm{CMC}$ and turned into beads by the crosslinking agent $\left(\mathrm{AlCl}_{3}\right)$ before being coated with chitosan. XRD, FT-IR, SEM and EDX were used to characterize $\mathrm{CuO}-\mathrm{Co}_{2} \mathrm{O}_{3}, \mathrm{CMC} / \mathrm{CuO}-\mathrm{Co}_{2} \mathrm{O}_{3}, \mathrm{Cs} @ \mathrm{CMC} / \mathrm{CuO}-\mathrm{Co}_{2} \mathrm{O}_{3}$ and $\mathrm{CuO}-\mathrm{Co}_{2} \mathrm{O}_{3}$. The findings confirm that $\mathrm{Cs} @ \mathrm{CMC} / \mathrm{CuO}-\mathrm{Co}_{2} \mathrm{O}_{3}$ is an efficient adsorbent toward $\mathrm{Ni}$ ions compared to other selected metal ions. Additionally, Ni/Cs@CMC/CuO- $\mathrm{Co}_{2} \mathrm{O}_{3}$ was used as a catalyst for degradation of $\mathrm{MO}$ and $\mathrm{EY}$ as well as catalytic reduction of $\mathrm{K}_{3}\left[\mathrm{Fe}(\mathrm{CN})_{6}\right]$ and 4-NP. This catalyst could be recycled and was able to be used up to five times, confirming the effectiveness and the stability of catalyst.

\section{Experimental}

\subsection{Materials}

Metal salts of $\mathrm{CoSO}_{4} \cdot 6 \mathrm{H}_{2} \mathrm{O}(99.998 \%), \mathrm{CuSO}_{4} \cdot 5 \mathrm{H}_{2} \mathrm{O}(\geq 98.0 \%), \mathrm{Ni}\left(\mathrm{NO}_{3} \cdot 6 \mathrm{H}_{2} \mathrm{O},(99.999 \%)\right.$ $\mathrm{FeSO}_{4} \cdot 7 \mathrm{H}_{2} \mathrm{O}(\geq 99.0 \%), \mathrm{AgNO}_{3}, \mathrm{ZnSO}_{4} \cdot 7 \mathrm{H}_{2} \mathrm{O}(\geq 99.0 \%)$ and $\mathrm{AlCl}_{3}(99.999 \%)$ were obtained from Sigma-Aldrich. Biopolymers: chitosan and carboxymethylcellulose were obtained from BDH chemicals. Organic compounds including dyes (Methyl Orange $(\mathrm{MO},(85 \%))$ and Eosin yellowish (EY, (5 wt.\% in $\left.\mathrm{H}_{2} \mathrm{O}\right)$ ) and 4-nitrophenol (4-NP, $(\geq 99 \%)$ ) were obtained from Sigma-Aldrich. Potassium hexacyanoferrate (III), $(99 \%)$ and the reducing agent (sodium borohydride, $(99 \%)$ ) were obtained from Sigma-Aldrich. In all preparations, deionized water was utilized.

\subsection{Synthesis of Nanocomposites and Beads}

\subsubsection{Preparation of $\mathrm{CuO}-\mathrm{Co}_{2} \mathrm{O}_{3}$ Nanocomposite}

The nanocomposite, $\mathrm{CuO}-\mathrm{Co}_{2} \mathrm{O}_{3}$ was prepared by co-precipitation method. Firstly, $0.1 \mathrm{M} \mathrm{CuSO}_{4} \cdot 5 \mathrm{H}_{2} \mathrm{O}$ was mixed with $0.1 \mathrm{M} \mathrm{CoSO}_{4} \cdot 6 \mathrm{H}_{2} \mathrm{O}$ in a (50:50) ratio. Then, $\mathrm{NaOH}$ was added dropwise to adjust the $\mathrm{pH}, 10-11$. The preparation was carried out at $80^{\circ} \mathrm{C}$ with stirring for $4 \mathrm{~h}$. Finally, the precipitate was collected via filtration, then washed several times with deionized water and dried overnight. Afterward, the $\mathrm{CuO}-\mathrm{Co}_{2} \mathrm{O}_{3}$ nanocomposite was calcined at $500{ }^{\circ} \mathrm{C}$ for $5 \mathrm{~h}$.

\subsubsection{Synthesis of $\mathrm{Cs} @ \mathrm{CMC} / \mathrm{CuO}-\mathrm{Co}_{2} \mathrm{O}_{3}$ Beads}

The novel nanocomposite beads were synthesized in two main steps. The method was reported by our group with some modifications [4,21]. The first step, CMC $(0.5 \mathrm{~g})$ was dissolved in $(25 \mathrm{~mL})$ with stirring for $2 \mathrm{~h}$ at $50{ }^{\circ} \mathrm{C}$. Meanwhile, $60 \mathrm{mg}$ of $\mathrm{CuO}-\mathrm{Co}_{2} \mathrm{O}_{3}$ powder was dissolved in $5 \mathrm{~mL}$ of deionized water and further sonicated for around $10 \mathrm{~min}$ for suspension of $\mathrm{CuO}-\mathrm{Co}_{2} \mathrm{O}_{3}$. Subsequently, $\mathrm{CuO}-\mathrm{Co}_{2} \mathrm{O}_{3}$ dispersed solution was added into $\mathrm{CMC}$ solution with continuous stirring for $1 \mathrm{~h}$ at $50{ }^{\circ} \mathrm{C}$, and half an hour at RT $\left(24^{\circ} \mathrm{C}\right)$. The mixture was transferred to $3 \mathrm{~mL}$ syringe and dropped into $0.2 \mathrm{M} \mathrm{AlCl}_{3}$ solution for crosslinking and formation of beads. The beads were kept in $\mathrm{AlCl}_{3}$ solution for $12 \mathrm{~h}$ and then collected and washed three times using deionized water. Secondly, Cs solution was prepared in $1 \%$ acetic acid distilled water mixture and stirred for $3 \mathrm{~h}$ at $50{ }^{\circ} \mathrm{C}$. The washed beads were transferred to $\mathrm{Cs}$ solution and kept for $1 \mathrm{~h}$. Finally, the $\mathrm{Cs} @ \mathrm{CMC} / \mathrm{CuO}-\mathrm{Co}_{2} \mathrm{O}_{3}$ beads were separated and dried at RT for $24 \mathrm{~h}$. Dry $\mathrm{CMC} / \mathrm{CuO}-\mathrm{Co}_{2} \mathrm{O}_{3}$ beads were flat, while the dry $\mathrm{Cs} @ \mathrm{CMC} / \mathrm{CuO}-\mathrm{Co}_{2} \mathrm{O}_{3}$ beads had a circle shape due to their chitosan coating, Figure 17. 


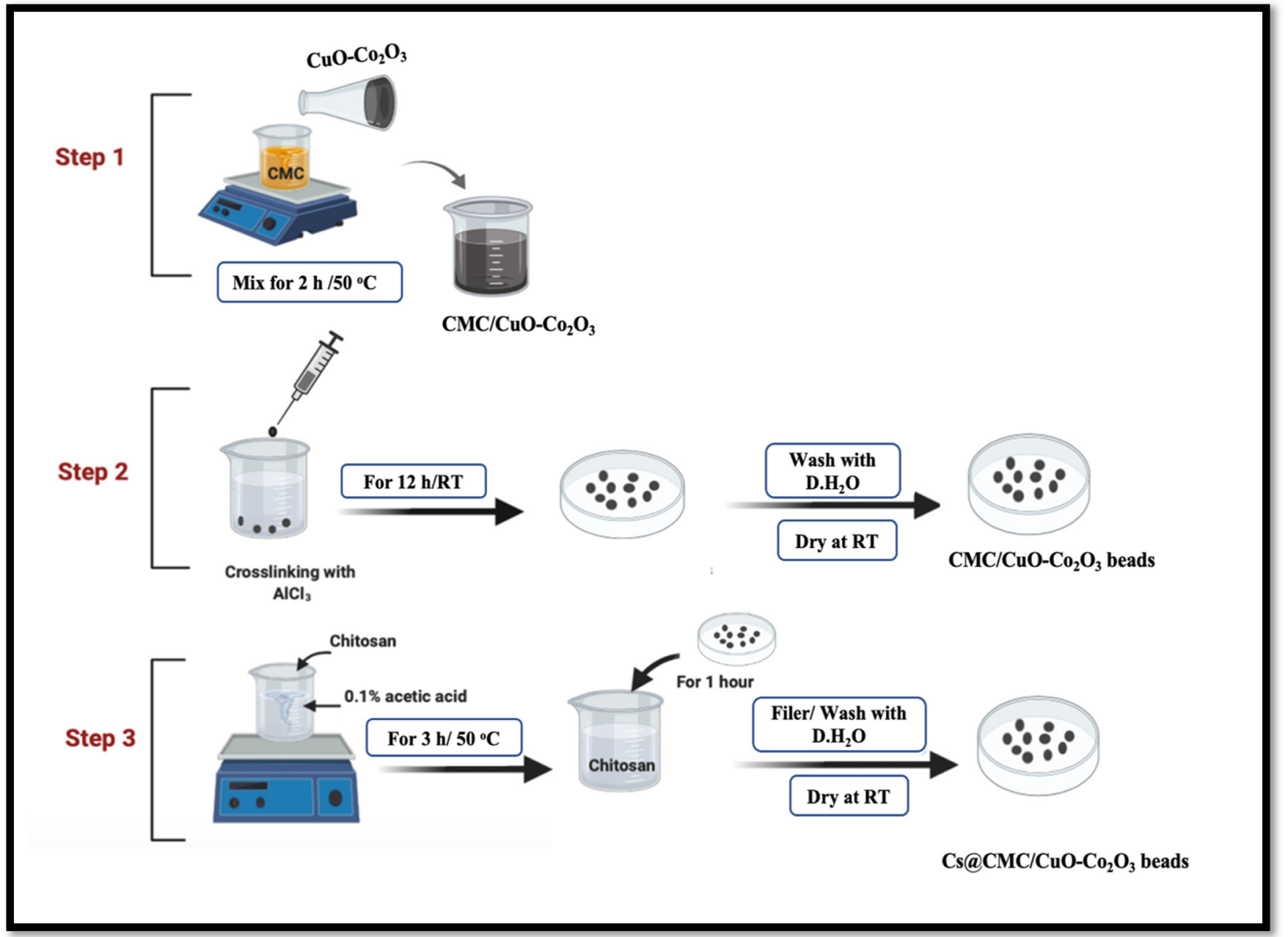

Figure 17. Preparation of $\mathrm{CMC} / \mathrm{CuO}-\mathrm{Co}_{2} \mathrm{O}_{3}$ and $\mathrm{Cs} @ \mathrm{CMC} / \mathrm{CuO}-\mathrm{Co}_{2} \mathrm{O}_{3}$ nanocomposite beads. $\mathrm{CMC}$ was dissolved in $(25 \mathrm{~mL})$ with stirring for $2 \mathrm{~h}$ under $50{ }^{\circ} \mathrm{C}$. $\mathrm{CuO}-\mathrm{Co}_{2} \mathrm{O}_{3}$ was dissolved in $5 \mathrm{~mL}$ of D. $\mathrm{H}_{2} \mathrm{O}$ and sonicated for around $10 \mathrm{~min}$. $\mathrm{CuO}-\mathrm{Co}_{2} \mathrm{O}_{3}$ solution was mixed with $\mathrm{CMC}$ solution at $50{ }^{\circ} \mathrm{C}$.

\subsection{Metal Uptake Adsorption}

In order to evaluate the selectivity of the prepared nanocomposite beads (Cs@CMC/ $\mathrm{CuO}-\mathrm{Co}_{2} \mathrm{O}_{3}$ and $\mathrm{CMC} / \mathrm{CuO}-\mathrm{Co}_{2} \mathrm{O}_{3}$ ), adsorption methods of metal ions were developed toward certain metal ions including $\mathrm{Ni}(\mathrm{II}), \mathrm{Ag}(\mathrm{I}), \mathrm{Zn}(\mathrm{II})$, and $\mathrm{Fe}(\mathrm{II})$. Certain amounts of $\mathrm{Cs} @ \mathrm{CMC} / \mathrm{CuO}-\mathrm{Co}_{2} \mathrm{O}_{3}$ and $\mathrm{CMC} / \mathrm{CuO}-\mathrm{Co}_{2} \mathrm{O}_{3}(5.0 \mathrm{mg})$ were added individually into $5 \mathrm{~mL}$ of 5 ppm of sample solution of selected metal ions for $1 \mathrm{~h}$ at RT $\left(25 \pm 1^{\circ} \mathrm{C}\right)$. The beads were separated from the solutions and dried at RT. The inductively coupled plasma-optical emission spectroscopy (ICP-OES) was employed to detect the concentration of each metal ion before and after adsorption on $\mathrm{Cs} @ \mathrm{CMC} / \mathrm{CuO}-\mathrm{Co}_{2} \mathrm{O}_{3}$ and $\mathrm{CMC} / \mathrm{CuO}-\mathrm{Co}_{2} \mathrm{O}_{3}$ beads. Optimization of parameters of the selected metal ions $\mathrm{Ni}(\mathrm{II})$ was carried out as mentioned later. Moreover, the Ag (I) beads were also kept after adsorption and converted to NPs for further studies.

For isotherm study, $5 \mathrm{mg}$ of each adsorbent $\mathrm{Cs} @ \mathrm{CMC} / \mathrm{CuO}-\mathrm{Co}_{2} \mathrm{O}_{3}$ and $\mathrm{CMC} / \mathrm{CuO}-\mathrm{Co}_{2} \mathrm{O}_{3}$ beads was added to $5 \mathrm{~mL}$ of Ni solution with initial concentrations from $\left(5-100 \mathrm{mg} \mathrm{L}^{-1}\right)$. The $\mathrm{pH}$ value of $\mathrm{Ni}$ solution was adjusted to $\mathrm{pH}=7$, with mechanical shaking for $60 \mathrm{~min}$.

Moreover, for kinetic study, $5 \mathrm{mg}$ of each adsorbent $\mathrm{Cs} @ \mathrm{CMC} / \mathrm{CuO}-\mathrm{Co}_{2} \mathrm{O}_{3}$ and $\mathrm{CMC} / \mathrm{CuO}-\mathrm{Co}_{2} \mathrm{O}_{3}$ bead was added to $5 \mathrm{~mL}$ of $5 \mathrm{mgL}^{-1} \mathrm{Ni}$ solution. The $\mathrm{pH}$ value of $\mathrm{Ni}$ solution was adjusted to $\mathrm{pH}=7$. The concentration of $\mathrm{Ni}$ ions was tested at different times $(10,30,60,120,240 \mathrm{~min})$. 


\subsection{Formation of Zero-Valent Nanoparticles}

$\mathrm{Ni}(\mathrm{II}) / \mathrm{Cs} @ \mathrm{CMC} / \mathrm{CuO}-\mathrm{Co}_{2} \mathrm{O}_{3}$ and $\mathrm{Ag}(\mathrm{I}) / \mathrm{CMC} / \mathrm{CuO}-\mathrm{Co}_{2} \mathrm{O}_{3}$ beads were collected and dried. These dried beads were later utilized for the synthesis of nanoparticles (Figure 18) by loading them into a freshly prepared $0.05 \mathrm{M} \mathrm{NaBH}_{4}$ aqueous solution for 20 min in order to complete the reduction of $\mathrm{Ni}(\mathrm{II})$ and $\mathrm{Ag}(\mathrm{I})$ to $\mathrm{Ni}(0)$ and $\mathrm{Ag}(0)$ zero-valent nanoparticles, respectively, as shown in the following Equations (9) and (10).

$$
\begin{gathered}
\mathrm{M}^{2+}+4 \mathrm{BH}_{4}{ }^{-}+12 \mathrm{H}_{2} \mathrm{O} \rightarrow 2 \mathrm{M}^{0}+14 \mathrm{H}_{2}+4 \mathrm{~B}(\mathrm{OH})_{3} \\
\mathrm{M}^{+}+2 \mathrm{BH}_{4}{ }^{-}+6 \mathrm{H}_{2} \mathrm{O} \rightarrow \mathrm{M}^{0}+7 \mathrm{H}_{2}+2 \mathrm{~B}(\mathrm{OH})_{3}
\end{gathered}
$$

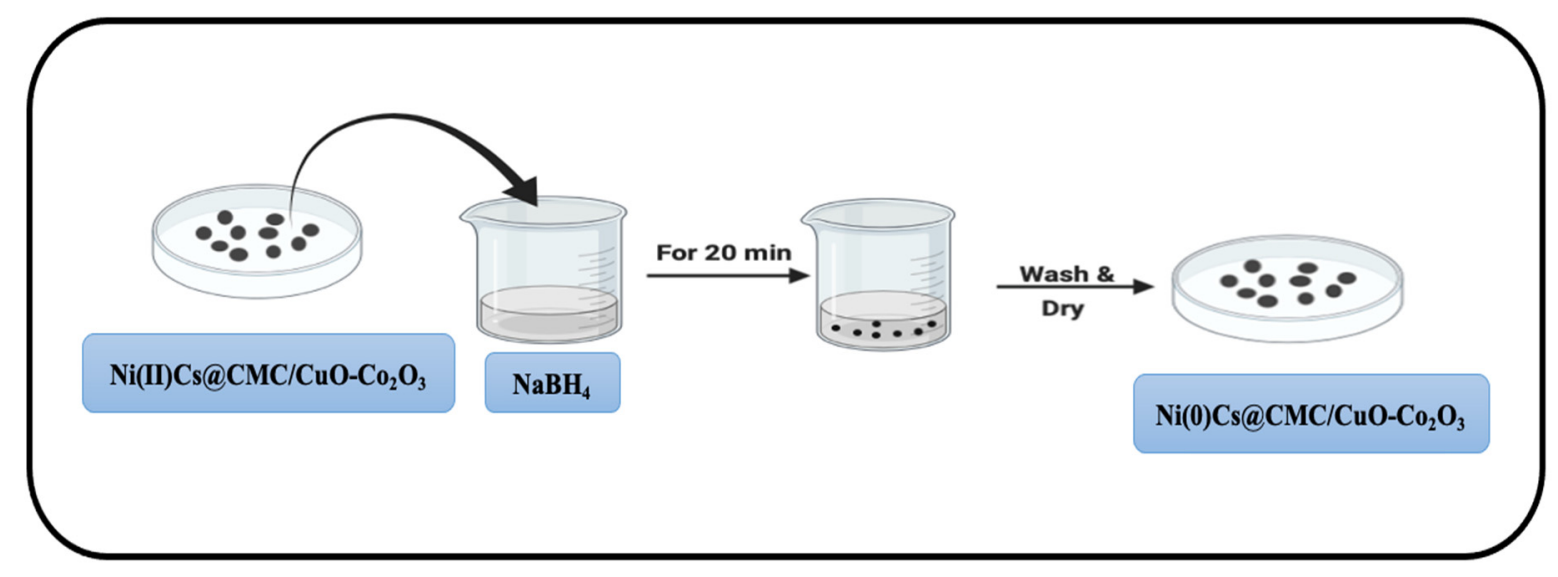

Figure 18. Reduction of $\mathrm{Ni}(\mathrm{II}) \mathrm{Cs} @ \mathrm{CMC} / \mathrm{CuO}-\mathrm{Co}_{2} \mathrm{O}_{3}$ beads to $\mathrm{Ni}(0) \mathrm{Cs} @ \mathrm{CMC} / \mathrm{CuO}-\mathrm{Co}_{2} \mathrm{O}_{3}$.

\subsection{Catalytic Reduction Experiments}

The catalytic ability of prepared catalysts, $\mathrm{Ni} / \mathrm{Cs} @ \mathrm{CMC} / \mathrm{CuO}-\mathrm{Co}_{2} \mathrm{O}_{3}, \mathrm{Cs} @ \mathrm{CMC} / \mathrm{CuO}-$ $\mathrm{Co}_{2} \mathrm{O}_{3}, \mathrm{CMC} / \mathrm{CuO}-\mathrm{Co}_{2} \mathrm{O}_{3}$ and $\mathrm{CuO}-\mathrm{Co}_{2} \mathrm{O}_{3}$, was investigated toward organic and inorganic pollutants. Firstly, $0.01 \mathrm{mM} \mathrm{MO}$ and EY, $0.1 \mathrm{mM} 4-\mathrm{NP}$ and $0.5 \mathrm{mM} \mathrm{K}_{3}\left[\mathrm{Fe}(\mathrm{CN})_{6}\right]$ were tested using $0.1 \mathrm{M} \mathrm{NaBH}_{4}$ and $5 \mathrm{mg}$ of each prepared catalyst individually, including $\mathrm{Ni} / \mathrm{Cs} @ \mathrm{CMC} / \mathrm{CuO}-\mathrm{Co}_{2} \mathrm{O}_{3}, \mathrm{Cs} @ \mathrm{CMC} / \mathrm{CuO}-\mathrm{Co}_{2} \mathrm{O}_{3}, \mathrm{CMC} / \mathrm{CuO}-\mathrm{Co}_{2} \mathrm{O}_{3}$ and $\mathrm{CuO}-$ $\mathrm{Co}_{2} \mathrm{O}_{3}$. Different concentrations of $\mathrm{MO}$ and $\mathrm{EY}(0.01,0.04$ and $0.08 \mathrm{mM}), 4-\mathrm{NP}(0.1$ and $0.04,0.08 \mathrm{mM})$ and $\mathrm{K}_{3}\left[\mathrm{Fe}(\mathrm{CN})_{6}\right](0.1 \mathrm{mM}, 0.5 \mathrm{mM})$ were then examined by utilizing $\mathrm{Ni} / \mathrm{Cs} @ \mathrm{CMC} / \mathrm{CuO}-\mathrm{Co}_{2} \mathrm{O}_{3}$ nanoparticles beads. Additionally, different concentrations of $\mathrm{NaBH}_{4}(0.05,0.1$ and $0.2 \mathrm{M})$ were tested using $0.01 \mathrm{mM} \mathrm{MO}$ and EY, $0.1 \mathrm{mM}$ 4-NP and $0.5 \mathrm{mM} \mathrm{K}_{3}\left[\mathrm{Fe}(\mathrm{CN})_{6}\right]$ with $5 \mathrm{mg}$ of $\mathrm{Ni} / \mathrm{Cs} @ \mathrm{CMC} / \mathrm{CuO}-\mathrm{Co}_{2} \mathrm{O}_{3}$ nanoparticles bead catalyst. Moreover, different amounts $(3,5$ and $8 \mathrm{mg})$ of $\mathrm{Ni} / \mathrm{Cs} @ \mathrm{CMC} / \mathrm{CuO}-\mathrm{Co}_{2} \mathrm{O}_{3}$ beads were tested using $0.01 \mathrm{mM} \mathrm{MO}$ and $0.5 \mathrm{mM} \mathrm{K}_{3}\left[\mathrm{Fe}(\mathrm{CN})_{6}\right]$ with $0.2 \mathrm{M} \mathrm{NaBH}_{4}$.

The catalytic procedure was performed by placing $2.5 \mathrm{~mL}$ of each pollutant $(\mathrm{MO}, \mathrm{EY}, 4-$ $\mathrm{NP}$ and $\mathrm{K}_{3}\left[\mathrm{Fe}(\mathrm{CN})_{6}\right]$ ) in a UV cuvette, and $0.5 \mathrm{~mL}$ of a freshly prepared solution of $\mathrm{NaBH}_{4}$ $(0.1 \mathrm{M})$ was added. Then, $5 \mathrm{mg}$ of the prepared catalyst and $\mathrm{NaBH}_{4}$ were both added to the mixture in the cuvette. Catalytic activity was continuously examined via UV-vis spectrophotometer with every 1 min interval. The recyclability of $\mathrm{Ni} / \mathrm{Cs} @ \mathrm{CMC} / \mathrm{CuO}$ $\mathrm{Co}_{2} \mathrm{O}_{3}$ beads was tested in the catalytic reduction of $\mathrm{MO}, \mathrm{EY}$ and $\mathrm{K}_{3}\left[\mathrm{Fe}(\mathrm{CN})_{6}\right]$. This catalyst was used up to five times after washing with deionized water and $\mathrm{MeOH}$ and dried for the next cycle.

The conversion (\%) of all compounds was calculated by utilizing Equation (11):

$$
\% R=\frac{C_{0}-C_{t}}{C_{0}} * 100
$$

where $C_{0}\left(\mathrm{mgL}^{-1}\right)$ is the initial concentration of compounds, and $C_{e}\left(\mathrm{mgL}^{-1}\right)$ is the final concentration. 
The rate constant $K$ and adjacent $R^{2}$ values were determined from pseudo-first-order kinetics as described below in Equation (12):

$$
\ln \frac{C_{t}}{C_{0}}=-K t
$$

\subsection{Characterization}

The morphologies and structures of Ni/Cs@CMC/CuO-Co $\mathrm{O}_{3}, \mathrm{Cs} @ \mathrm{CMC} / \mathrm{CuO}-$ $\mathrm{Co}_{2} \mathrm{O}_{3}, \mathrm{CMC} / \mathrm{CuO}-\mathrm{Co}_{2} \mathrm{O}_{3}$ and $\mathrm{CuO}-\mathrm{Co}_{2} \mathrm{O}_{3}$ were characterized by scanning electron microscope (SEM) (of JEOL, JSM-7600F, Japan). For SEM analysis, Ni/Cs@CMC/CuO-Co $\mathrm{O}_{3}$, $\mathrm{Cs} @ \mathrm{CMC} / \mathrm{CuO}-\mathrm{Co}_{2} \mathrm{O}_{3}, \mathrm{CMC} / \mathrm{CuO}-\mathrm{Co}_{2} \mathrm{O}_{3}$ and $\mathrm{CuO}-\mathrm{Co}_{2} \mathrm{O}_{3}$ were individually fixed on the stub using carbon tape as a binder and then sputtered with platinum for $15 \mathrm{~s}$. In addition, X-ray diffraction (XRD) was employed to examine the phase structure of all prepared catalysts. Elemental analysis of $\mathrm{Ni} / \mathrm{Cs} @ \mathrm{CMC} / \mathrm{CuO}-\mathrm{Co}_{2} \mathrm{O}_{3}, \mathrm{Cs} @ \mathrm{CMC} / \mathrm{CuO}-\mathrm{Co}_{2} \mathrm{O}_{3}$, $\mathrm{CMC} / \mathrm{CuO}-\mathrm{Co}_{2} \mathrm{O}_{3}$ and $\mathrm{CuO}-\mathrm{Co}_{2} \mathrm{O}_{3}$ was analyzed by energy dispersive spectrometer (EDS). FTIR spectrometer was applied to analyze the spectra of all prepared materials. The catalytic reduction studies were recorded by UV-vis spectra, (Thermo Scientific TM Evolution TM 350 UV-vis spectrophotometer).

Author Contributions: Conceptualization, E.M.B. and S.B.K.; methodology, N.M.; software, E.Y.D.; validation, K.A., X.S. and A.M.A.; formal analysis, T.M.F.; investigation, X.S.; resources, A.M.A.; data curation, N.M.; writing-original draft preparation, N.M.; writing—review and editing, T.M.F.; visualization, S.B.K.; supervision, E.Y.D.; project administration, K.A.; funding acquisition, E.M.B. All authors have read and agreed to the published version of the manuscript.

Funding: This research was funded by Deputyship for Research \& Innovation, Ministry of Education in Saudi Arabia under grant number (IFPRC-061-247-2020).

Institutional Review Board Statement: Not applicable.

Informed Consent Statement: Not applicable.

Data Availability Statement: The data presented in this study are available on request from the corresponding author.

Acknowledgments: The authors extend their appreciation to the Deputyship for Research \& Innovation, Ministry of Education in Saudi Arabia for funding this research work through the project number (IFPRC-061-247-2020) and King Abdulaziz University, DSR, Jeddah, Saudi Arabia.

Conflicts of Interest: The authors declare no conflict of interest.

\section{References}

1. Crini, G. Non-Conventional Low-Cost Adsorbents for Dye Removal: A Review. Bioresour. Technol. 2006, 97, 1061-1085. [CrossRef] [PubMed]

2. Omidvar, A.; Jaleh, B.; Nasrollahzadeh, M. Preparation of the GO/Pd Nanocomposite and Its Application for the Degradation of Organic Dyes in Water. J. Colloid Interface Sci. 2017, 496, 44-50. [CrossRef] [PubMed]

3. Veerakumar, P.; Salamalai, K.; Thanasekaran, P.; Lin, K.C. Simple Preparation of Porous Carbon-Supported Ruthenium: Propitious Catalytic Activity in the Reduction of Ferrocyanate(III) and a Cationic Dye. ACS Omega 2018, 3, 12609-12621. [CrossRef] [PubMed]

4. Maslamani, N.; Khan, S.B.; Danish, E.Y.; Bakhsh, E.M.; Zakeeruddin, S.M.; Asiri, A.M. Carboxymethyl Cellulose Nanocomposite Beads as Super-Efficient Catalyst for the Reduction of Organic and Inorganic Pollutants. Int. J. Biol. Macromol. 2021, 167, 101-116. [CrossRef]

5. Kavak, D. Removal of Lead from Aqueous Solutions by Precipitation: Statistical Analysis and Modeling. Desalination Water Treat. 2013, 51, 1720-1726. [CrossRef]

6. Trivunac, K.; Stevanovic, S. Removal of Heavy Metal Ions from Water by Complexation-Assisted Ultrafiltration. Chemosphere 2006, 64, 486-491. [CrossRef]

7. Maslamani, N.; Manandhar, E.; Geremia, D.K.; Logue, B.A. ICE Concentration Linked with Extractive Stirrer (ICECLES). Anal. Chim. Acta 2016, 941, 41-48. [CrossRef]

8. Mende, M.; Schwarz, D.; Steinbach, C.; Boldt, R.; Schwarz, S. Simultaneous Adsorption of Heavy Metal Ions and Anions from Aqueous Solutions on Chitosan-Investigated by Spectrophotometry and SEM-EDX Analysis. Colloids Surf. A Physicochem. Eng. Asp. 2016, 510, 275-282. [CrossRef] 
9. Nageeb, M. Adsorption Technique for the Removal of Organic Pollutants from Water and Wastewater. Org. Pollut. Monit. Risk Treat. 2013, 7, 167-194.

10. Schieder, D.; Dobias, B.; Klumpp, E.; Schwuger, M.J. Adsorption and Solubilisation of Phenols in the Hexadecyltrimethylammonium Chloride Adsorbed Layer on Quartz and Corundum. Colloids Surf. A Physicochem. Eng. Asp. 1994, 88, $103-111$. [CrossRef]

11. Almeida, C.A.P.; Debacher, N.A.; Downs, A.J.; Cottet, L.; Mello, C.A.D. Removal of Methylene Blue from Colored Effluents by Adsorption on Montmorillonite Clay. J. Colloid Interface Sci. 2009, 332, 46-53. [CrossRef] [PubMed]

12. Girods, P.; Dufour, A.; Fierro, V.; Rogaume, Y.; Rogaume, C.; Zoulalian, A.; Celzard, A. Activated Carbons Prepared from Wood Particleboard Wastes: Characterisation and Phenol Adsorption Capacities. J. Hazard. Mater. 2009, 166, 491-501. [CrossRef] [PubMed]

13. Aksu, Z. Biosorption of Reactive Dyes by Dried Activated Sludge: Equilibrium and Kinetic Modelling. Biochem. Eng. J. 2001, 7 , 79-84. [CrossRef]

14. Sun, X.; Shen, J.; Yu, D.; Ouyang, X.-K. Preparation of pH-Sensitive $\mathrm{Fe}_{3} \mathrm{O}_{4} @ \mathrm{C} / \mathrm{Carboxymethyl} \mathrm{Cellulose/Chitosan} \mathrm{Composite}$ Beads for Diclofenac Sodium Delivery. Int. J. Biol. Macromol. 2019, 127, 594-605. [CrossRef] [PubMed]

15. Bakhsh, E.M.; Ali, F.; Khan, S.B.; Marwani, H.M.; Danish, E.Y.; Asiri, A.M. Copper Nanoparticles Embedded Chitosan for Efficient Detection and Reduction of Nitroaniline. Int. J. Biol. Macromol. 2019, 131, 666-675. [CrossRef]

16. Dhillon, G.S.; Kaur, S.; Brar, S.K. Facile Fabrication and Characterization of Chitosan-Based Zinc Oxide Nanoparticles and Evaluation of Their Antimicrobial and Antibiofilm Activity. Int. Nano Lett. 2014, 4, 107. [CrossRef]

17. Mahmoud, M.E.; Abdou, A.E.H.; Sobhy, M.E.; Fekry, N.A. Solid-Solid Crosslinking of Carboxymethyl Cellulose Nanolayer on Titanium Oxide Nanoparticles as a Novel Biocomposite for Efficient Removal of Toxic Heavy Metals from Water. Int. J. Biol. Macromol. 2017, 105, 1269-1278. [CrossRef]

18. Saber-Samandari, S.; Saber-Samandari, S.; Joneidi-Yekta, H.; Mohseni, M. Adsorption of Anionic and Cationic Dyes from Aqueous Solution Using Gelatin-Based Magnetic Nanocomposite Beads Comprising Carboxylic Acid Functionalized Carbon Nanotube. Chem. Eng. J. 2017, 308, 1133-1144. [CrossRef]

19. Zhang, Y.; Liu, Y.; Wang, X.; Sun, Z.; Ma, J.; Wu, T.; Xing, F.; Gao, J. Porous graphene oxide/carboxymethyl cellulose monoliths, with high metal ion adsorption. Carbohydr. Polym. 2014, 101, 392-400. [CrossRef]

20. Behzadi Nia, S.; Pooresmaeil, M.; Namazi, H. Carboxymethylcellulose/Layered Double Hydroxides Bio-Nanocomposite Hydrogel: A Controlled Amoxicillin Nanocarrier for Colonic Bacterial Infections Treatment. Int. J. Biol. Macromol. 2020, 155, 1401-1409.

21. Maslamani, N.; Khan, S.B.; Danish, E.Y.; Bakhsh, E.M.; Zakeeruddin, S.M.; Asiri, A.M. Super Adsorption Performance of Carboxymethyl Cellulose/Copper Oxide-Nickel Oxide Nanocomposite toward the Removal of Organic and Inorganic Pollutants. Environ. Sci. Pollut. Res. 2021, 28, 38476-38496. [CrossRef] [PubMed]

22. Rasoulzadeh, M.; Namazi, H. Carboxymethyl Cellulose/Graphene Oxide Bio-Nanocomposite Hydrogel Beads as Anticancer Drug Carrier Agent. Carbohydr. Polym. 2017, 168, 320-326. [CrossRef] [PubMed]

23. Crini, G. Recent Developments in Polysaccharide-Based Materials Used as Adsorbents in Wastewater Treatment. Prog. Polym. Sci. 2005, 30, 38-70. [CrossRef]

24. Vakili, M.; Deng, S.; Cagnetta, G.; Wang, W.; Meng, P.; Liu, D.; Yu, G. Regeneration of Chitosan-Based Adsorbents Used in Heavy Metal Adsorption: A Review. Sep. Purif. Technol. 2019, 224, 373-387. [CrossRef]

25. Yusof, N.A.A.; Zain, N.M.; Pauzi, N. Synthesis of Chitosan/Zinc Oxide Nanoparticles Stabilized by Chitosan via Microwave Heating. Bull. Chem. React. Eng. Catal. 2019, 14, 450-458. [CrossRef]

26. Ibrahim, A.G.; Saleh, A.S.; Elsharma, E.M.; Metwally, E.; Siyam, T. Chitosan g maleic Acid for Effective Removal of Copper and Nickel Ions from Their Solutions. Int. J. Biol. Macromol. 2019, 121, 1287-1294. [CrossRef]

27. Jang, E.S.; Khan, S.B.; Seo, J.; Nam, Y.H.; Choi, W.J.; Akhtar, K.; Han, H. Synthesis and characterization of novel UV-curable polyurethane-clay nanohybrid: Influence of organically modified layered silicates on the properties of polyurethane. Prog. Organ. Coat. 2011, 71, 36-42. [CrossRef]

28. Kim, D.; Jung, J.; Kim, Y.; Lee, M.; Seo, J.; Khan, S.B. Structure and thermal properties of octadecane/expanded graphite composites as shape-stabilized phase change materials. Int. J. Heat Mass Trans. 2016, 95, 735-741. [CrossRef]

29. Khan, S.B.; Rahman, M.M.; Jang, E.S.; Akhtar, K.; Han, H. Special susceptive aqueous ammonia chemi-sensor: Extended applications of novel UV-curable polyurethane-clay nanohybrid. Talanta 2011, 84, 1005-1010. [CrossRef]

30. Ismail, M.; Khan, M.; Akhtar, K.; Khan, M.A.; Asiri, A.M.; Khan, S.B. Biosynthesis of Silver Nanoparticles: A Colorimetric Optical Sensor for Detection of Hexavalent Chromium and Ammonia in Aqueous Solution. Available online: https://www.sciencedirect. com/science/article/abs/pii/S1386947718301279 (accessed on 19 January 2022). [CrossRef]

31. Kamal, T.; Ahmad, I.; Khan, S.B.; Asiri, A.M. Bacterial cellulose as support for biopolymer stabilized catalytic cobalt nanoparticles. Int. J. Biol. Macromol. 2019, 135, 1162-1170. [CrossRef]

32. Jang, E.S.; Khan, S.B.; Seo, J.; Akhtar, K.; Choi, J.; Kim, K.I.; Han, H. Synthesis and characterization of novel UV-Curable PU-Si hybrids: Influence of silica on thermal, mechanical, and water sorption properties of polyurethane acrylates. Macromol. Res. 2011, 19, 1006-1013. [CrossRef]

33. Kamal, T.; Ali, N.; A Naseem, A.; B Khan, S.; M Asiri, A. Polymer nanocomposite membranes for antifouling nanofiltration. Recent. Pat. Nanotechnol. 2016, 10, 189-201. [CrossRef] [PubMed] 
34. Lee, Y.; Kim, D.; Seo, J.; Han, H.; Khan, S.B. Preparation and characterization of poly (propylene carbonate)/exfoliated graphite nanocomposite films with improved thermal stability, mechanical properties and barrier properties. Poly. Int. 2013, 62, 1386-1394. [CrossRef]

35. Sharma, G.; Kumar, A.; Sharma, S.; Naushad, M.; Ghfar, A.A.; Ala'a, H.; Ahamad, T.; Sharma, N.; Stadler, F.J. Carboxymethyl cellulose structured nano-adsorbent for removal of methyl violet from aqueous solution: Isotherm and kinetic analyses. Cellulose 2020, 27, 3677-3691. [CrossRef]

36. Ali, F.; Khan, S.B.; Kamal, T.; Alamry, K.A.; Asiri, A.M. Chitosan-Titanium Oxide Fibers Supported Zero-Valent Nanoparticles: Highly Efficient and Easily Retrievable Catalyst for the Removal of Organic Pollutants. Sci. Rep. 2018, 8, 6260. [CrossRef]

37. Ali, N.; Kamal, T.; Ul-Islam, M.; Khan, A.; Shah, S.J.; Zada, A. Chitosan-coated cotton cloth supported copper nanoparticles for toxic dye reduction. Int. J. Biol. Macromol. 2018, 111, 832-838. [CrossRef]

38. Rajeevgandhi, C.; Sathiyamurthy, K.; Guganathan, L.; Savithiri, S.; Bharanidharan, S.; Mohan, K. Experimental and Theoretical Investigations on the Spinel Structure of $\mathrm{CO}_{2} \mathrm{O}_{3}$ Nanoparticles Synthesized via Simple Co-Precipitation Method. J. Mater. Sci. Mater. Electron. 2020, 31, 16769-16779. [CrossRef]

39. Barkhordari, S.; Yadollahi, M.; Namazi, H. pH Sensitive Nanocomposite Hydrogel Beads Based on Carboxymethyl Cellulose/Layered Double Hydroxide as Drug Delivery Systems. J. Polym. Res. 2014, 21, 454. [CrossRef]

40. Roh, H.; Kim, Y.; Kim, Y.K.; Harbottle, D.; Lee, J.W. Amino-Functionalized Magnetic Chitosan Beads to Enhance Immobilization of Potassium Copper Hexacyanoferrate for Selective Cs ${ }^{+}$Removal and Facile Recovery. RSC Adv. 2019, 9, 1106-1114. [CrossRef]

41. Khan, S.A.; Riaz-ur-Rehman; Khan, M.A. Adsorption of Chromium (III), Chromium (VI) and Silver (I) on Bentonite. Waste Manag. 1995, 15, 271-282. [CrossRef]

42. Freire, T.M.; Fechine, L.M.U.D.; Queiroz, D.C.; Freire, R.M.; Denardin, J.C.; Ricardo, N.M.P.S.; Rodrigues, T.N.B.; Gondim, D.R.; Junior, I.J.S.; Fechine, P.B.A. Magnetic Porous Controlled $\mathrm{Fe}_{3} \mathrm{O}_{4}-$ Chitosan Nanostructure: An Ecofriendly Adsorbent for Efficient Removal of Azo Dyes. Nanomaterials 2020, 10, 1194. [CrossRef] [PubMed]

43. Tran, H.V.; Dai Tran, L.; Nguyen, T.N. Preparation of chitosan/magnetite composite beads and their application for removal of Pb (II) and Ni (II) from aqueous solution. Mater. Sci. Eng. C 2010, 30, 304-310. [CrossRef] [PubMed]

44. Hall, K.R.; Eagleton, L.C.; Acrivos, A.; Vermeulen, T. Pore- and Solid-Diffusion Kinetics in Fixed-Bed Adsorption under ConstantPattern Conditions. Ind. Eng. Chem. Fundam. 1966, 5, 212-223. [CrossRef]

45. Liu, X.; Hu, Q.; Fang, Z.; Zhang, X.; Zhang, B. Magnetic Chitosan Nanocomposites: A Useful Recyclable Tool for Heavy Metal Ion Removal. Langmuir 2009, 25, 3-8. [CrossRef]

46. Kaur, N.; Kaur, M.; Singh, D. Fabrication of Mesoporous Nanocomposite of Graphene Oxide with Magnesium Ferrite for Efficient Sequestration of $\mathrm{Ni}$ (II) and $\mathrm{Pb}$ (II) Ions: Adsorption, Thermodynamic and Kinetic Studies. Environ. Pollut. 2019, 253, 111-119. [CrossRef]

47. Vijaya, Y.; Popuri, S.R.; Boddu, V.M.; Krishnaiah, A. Modified Chitosan and Calcium Alginate Biopolymer Sorbents for Removal of Nickel (II) through Adsorption. Carbohydr. Polym. 2008, 72, 261-271. [CrossRef]

48. Kong, A.; Ji, Y.; Ma, H.; Song, Y.; He, B.; Li, J. A Novel Route for the Removal of Cu(II) and Ni(II) Ions via Homogeneous Adsorption by Chitosan Solution. J. Clean. Prod. 2018, 192, 801-808. [CrossRef]

49. Hao, Y.-M.; Man, C.; Hu, Z.-B. Effective removal of $\mathrm{Cu}$ (II) ions from aqueous solution by amino-functionalized magnetic nanoparticles. J. Hazard. Mater. 2010, 184, 392-399. [CrossRef]

50. Tseng, R.-L.; Wu, P.-H.; Wu, F.-C.; Juang, R.-S. A convenient method to determine kinetic parameters of adsorption processes by nonlinear regression of pseudo- ${ }^{\text {th }}$-order equation. Chem. Eng. J. 2014, 237, 153-161. [CrossRef]

51. Foo, K.Y.; Hameed, B.H. Insights into the modeling of adsorption isotherm systems. Chem. Eng. J. 2010, 156, 2-10. [CrossRef]

52. Jiang, D.; Yang, Y.; Huang, C.; Huang, M.; Chen, J.; Rao, T.; Ran, X. Removal of the Heavy Metal Ion Nickel (II) via an Adsorption Method Using Flower Globular Magnesium Hydroxide. J. Hazard. Mater. 2019, 373, 131-140. [CrossRef] [PubMed]

53. Wang, K.; Tao, X.; Xu, J.; Yin, N. Novel Chitosan-MOF Composite Adsorbent for the Removal of Heavy Metal Ions. Chem. Lett. 2016, 45, 1365-1368. [CrossRef]

54. Gibbs, G.; Tobin, J.M.; Guibal, E. Sorption of Acid Green 25 on Chitosan: Influence of Experimental Parameters on Uptake Kinetics and Sorption Isotherms. J. Appl. Polym. Sci. 2003, 90, 1073-1080. [CrossRef]

55. Guibal, E. Interactions of Metal Ions with Chitosan-Based Sorbents: A Review. Sep. Purif. Technol. 2004, 38, 43-74. [CrossRef]

56. Al-Ghamdi, Y.O.; Khan, S.A. Stabilization of zero-valent Au nanoparticles on carboxymethyl cellulose layer coated on chitosanCBV 780 zeolite Y sheets: Assessment in the reduction of 4-nitrophenol and dyes. Cellulose 2020, 27, 8827-8841. [CrossRef]

57. Amir, M.; Kurtan, U.; Baykal, A.; Sözeri, H. MnFe $\mathrm{O}_{4} @$ PANI@ Ag heterogeneous nanocatalyst for degradation of industrial aqueous organic pollutants. J. Mater. Sci. Tech. 2016, 32, 134-141. [CrossRef]

58. Vidhu, V.; Philip, D. Catalytic degradation of organic dyes using biosynthesized silver nanoparticles. Micron 2014, 56, 54-62 [CrossRef]

59. Tüysüz, H.; Hwang, Y.J.; Khan, S.B.; Asiri, A.M.; Yang, P. Mesoporous $\mathrm{Co}_{3} \mathrm{O}_{4}$ as an Electrocatalyst for Water Oxidation. Nano Res. 2013, 6, 47-54. [CrossRef]

60. Rasheed, T.; Nabeel, F.; Bilal, M.; Iqbal, H.M.N. Biogenic Synthesis and Characterization of Cobalt Oxide Nanoparticles for Catalytic Reduction of Direct Yellow-142 and Methyl Orange Dyes. Biocatal. Agric. Biotechnol. 2019, 19, 101154. [CrossRef]

61. Umamaheswari, C.; Lakshmanan, A.; Nagarajan, N.S. Green Synthesis, Characterization and Catalytic Degradation Studies of Gold Nanoparticles against Congo Red and Methyl Orange. J. Photochem. Photobiol. B Biol. 2018, 178, 33-39. [CrossRef] [PubMed] 
62. Ali, H.S.H.M.; Khan, S.A. Stabilization of Various Zero-Valent Metal Nanoparticles on a Superabsorbent Polymer for the Removal of Dyes, Nitrophenol, and Pathogenic Bacteria. ACS Omega 2020, 5, 7379-7391. [CrossRef] [PubMed]

63. Komalam, A.; Muraleegharan, L.G.; Subburaj, S.; Suseela, S.; Babu, A.; George, S. Designed Plasmonic Nanocatalysts for the Reduction of Eosin Y: Absorption and Fluorescence Study. Int. Nano Lett. 2012, 2, 26. [CrossRef]

64. Kamal, T.; Ahmad, I.; Khan, S.B.; Ul-Islam, M.; Asiri, A.M. Microwave Assisted Synthesis and Carboxymethyl Cellulose Stabilized Copper Nanoparticles on Bacterial Cellulose Nanofibers Support for Pollutants Degradation. J. Polym. Environ. 2019, 27, 2867-2877. [CrossRef]

65. Zhu, J.; Zhang, X.; Qin, Z.; Zhang, L.; Ye, Y.; Cao, M.; Gao, L.; Jiao, T. Preparation of PdNPs Doped Chitosan-Based Composite Hydrogels as Highly Efficient Catalysts for Reduction of 4-Nitrophenol. Colloids Surf. A Physicochem. Eng. Asp. 2021, 611, 125889. [CrossRef]

66. Kamal, T.; Khan, S.B.; Asiri, A.M. Nickel Nanoparticles-Chitosan Composite Coated Cellulose Filter Paper: An Efficient and Easily Recoverable Dip-Catalyst for Pollutants Degradation. Environ. Pollut. 2016, 218, 625-633. [CrossRef]

67. Nithiyanantham, U.; Ede, S.R.; Anantharaj, S.; Kundu, S. Self-Assembled $\mathrm{NiWO}_{4}$ Nanoparticles into Chain-like Aggregates on DNA Scaffold with Pronounced Catalytic and Supercapacitor Activities. Cryst. Growth Des. 2015, 15, 673-686. [CrossRef]

68. Xie, R.; Wei, T.; Bai, S.; Wang, Z.; Chai, F.; Chen, L.; Zang, S. The Synthesis and Catalytic Activity of Bimetallic CuAg Nanoparticles and Their Magnetic Hybrid Composite Materials. New J. Chem. 2020, 44, 9684-9690. [CrossRef]

69. Xia, Q.; Su, D.; Yang, X.; Chai, F.; Wang, C.; Jiang, J. One Pot Synthesis of Gold Hollow Nanospheres with Efficient and Reusable Catalysis. RSC Adv. 2015, 5, 58522-58527. [CrossRef]

70. Maslamani, N.; Khan, S.B.; Danish, E.Y.; Bakhsh, E.M.; Akhtar, K.; Asiri, A.M. Metal nanoparticles supported chitosan coated carboxymethyl cellulose beads as a catalyst for the selective removal of 4-nitrophenol. Chemosphere 2022, 291, 133010. [CrossRef] 